\title{
Does having highly educated adult children reduce mortality risks for parents with low educational attainment in Europe?
}

\author{
Albert Sabater $^{1 \star}$, Elspeth Graham ${ }^{1}$ and Alan Marshall ${ }^{2}$ \\ ${ }^{1}$ School of Geography and Sustainable Development \& ESRC Centre for Population Change, University of \\ St Andrews, St Andrews, UK and ${ }^{2}$ School of Social and Political Science, University of Edinburgh, \\ Edinburgh, UK \\ *Corresponding author. Email: albert.sabater@st-andrews.ac.uk
}

(Accepted 5 June 2019; first published online 19 July 2019)

\begin{abstract}
It is known that the education of significant others may affect an individual's mortality. This paper extends an emerging body of research by investigating the effect of having highly educated adult children on the longevity of older parents in Europe, especially parents with low educational attainment. Using a sample of 15,015 individuals $(6,620$ fathers and 8,395 mothers) aged 50 and above, with 1,847 recorded deaths, over a mean follow-up period of 10.9 years from the Survey of Health, Ageing and Retirement in Europe (SHARE), we examine whether the well-established socio-economic gradient in mortality among parents is modified when their adult children have higher educational attainment than their parents. We find that having highly educated adult children is associated with reduced mortality risks for fathers and mothers with low educational attainment, compared to their counterparts whose adult children have only compulsory education. The association is stronger in early older age (ages 50-74) than in later older age (ages 75 and over). Part of the association appears to be explained by health behaviours (physical (in)activity) and health status (self-rated health). Our findings suggest that the socioeconomic-mortality gradient among older parents might be better captured using an intergenerational approach that recognises the advantage of having highly educated adult children, especially for fathers and mothers with only compulsory education.
\end{abstract}

Keywords: mortality; older parents; adult children; intergenerational transfers; education

\section{Introduction}

It has been long recognised that individuals in lower socio-economic groups systematically experience higher mortality and worse health outcomes, resulting in a mortality gradient whereby life expectancy increases in step with socio-economic position (Marmot et al., 1987; Link and Phelan, 1995; Chapman et al., 2009; Elo, 2009). Previous research has shown the value of education for health (Backlund

(c) Cambridge University Press 2019. This is an Open Access article, distributed under the terms of the Creative Commons Attribution licence (http://creativecommons.org/licenses/by/4.0/), which permits unrestricted re-use, distribution, and reproduction in any medium, provided the original work is properly cited. 
et al., 1999; Huisman et al., 2005; Cutler and Lleras-Muney, 2010; Goldman and Smith, 2011; Delaruelle et al., 2015) and provided evidence that, compared to those who have little schooling, higher-educated people have more resources to influence their health and longevity positively (Ross and Van Willigen, 1997; Ross and Mirowsky, 1999; Huijts et al., 2010). It is not only an individual's own education that is associated with health benefits. The educational achievements of spouses may have an additional impact on an individual's mortality (Monden et al., 2003; Skalická and Kunst, 2008), as well as the average education level in their community (Kravdal, 2008). More recently, a new line of thinking has indicated that adult children's socio-economic status may also be associated with the health and mortality of their parents, with growing evidence from low- to high-income countries (Zimmer et al., 2002, 2007, 2016; Torssander, 2013, 2014; Friedman and Mare, 2014; Lundborg and Majlesi, 2015; Yahirun et al., 2016, 2017; Yang et al., 2016; De Neve and Harling, 2017; Elo et al., 2018; Smith-Greenaway et al., 2018).

The links between adult children's education and the health and mortality of their parents have been studied in diverse country settings. Research in the European context has been primarily dominated by studies using register-based data from Nordic countries such as Sweden (Torssander, 2013, 2014; Lundborg and Majlesi, 2015) and Finland (Elo et al., 2018). While multigeneration data from population registers clearly offer a way forward to document the association between parents' mortality and their adult children's educational attainment, further research is needed from the European context to reveal the extent of such a relationship within and beyond some of the most progressive welfare states in Europe.

Our study will extend the current body of research on upward health transfers by using Europe-wide comparable longitudinal data from the Survey of Health, Ageing and Retirement in Europe (SHARE). Many European countries experienced rapid industrialisation after the Second World War, as well as a continued expansion of educational opportunities (Breen, 2010; Busemeyer et al., 2018), leading to younger cohorts attaining higher levels of education than older cohorts. Thus, the rapid pace of educational expansion in Europe means that older parents in the early 21 st century are more likely than at other times in the past to reap health advantages via the education of their adult children.

The current study has three main objectives. Our first objective is to investigate whether any influence of having highly educated children on the longevity of older parents depends on the relative educational attainment of the parent and adult child. Intergenerational relationships are encapsulated in one of the central propositions of the lifecourse perspective, namely linked lives - that is, significant others or family members such as parents and children mutually influence each other's wellbeing (Elder $e t$ al., 2003). We argue that, in the context of educational expansion and the socio-economic gradient in health in Europe (Delaruelle et al., 2015), an examination of the differential influence on the longevity of older parents of the relative educational attainment of the parent and adult child is important because structural and behavioural factors may suppress or accentuate the benefits of adult children's education depending on the level of education of their parents. Although most studies on health inequalities focus on the associations between health and mortality based on one's own education, a linked lives approach may indeed be needed when studying health inequalities in Europe and the differential access to material and immaterial resources among vulnerable 
and advantaged groups (Mackenbach, 2012). For instance, if low education is particularly detrimental for the longevity of older parents, having highly educated adult children may be especially beneficial for this group. The study thus extends the existing literature on upward health transfers in Europe and beyond by examining the association between parent-child relative education and fathers' and mothers' longevity.

Our second objective is to examine when in the lifecourse adult children's education might have a greater influence on parents' longevity by taking into consideration an intergenerational approach that is sensitive both to educational differences and to the age of older parents. Prior research on upward health transfers has indicated that the association between adult children's education and parents' survival may be mediated by the age of older parents (Zimmer et al., 2007, 2016; Elo et al., 2018). This is in accordance with an extensive literature on socioeconomic disparities in mortality (Huisman et al., 2003, 2005; Von dem Knesebeck et al., 2006; Bambra et al., 2010), which suggests that while some causes of death strongly increase with age (e.g. cerebrovascular disease, pneumonia), others decline (e.g. cancer and external causes). However, since individuals in lower socioeconomic groups are more likely to experience poor health and retire for health reasons, it has also been suggested that health inequalities tend to amplify during early older age (Chandola et al., 2007) before diminishing in later life as a result of the (generally) widespread government support to the elderly in Western societies, universal biological frailty in old age and mortality selection (Cullati et al., 2014). We therefore examine whether the well-established educational gradient in mortality among parents is indeed modified when adult children have higher educational attainment than their parents in early (ages 50-74) and in later (ages 75 and over) older age.

Establishing a relationship between parental longevity and the educational attainment of adult children does not, of course, reveal the mechanism that might connect the two. Thus, the final part of the paper begins the task of exploring how adult children might influence their parents' health within the European context. The possible pathways through which such an influence might work remain poorly understood. Previous research from the United States of America (USA) has suggested that the association between adult children's education and parents' health is partly a function of the way in which the younger generation impacts upon health behaviours, such as physical activity, among the older generation (Friedman and Mare, 2014). Similarly, Torssander (2013) has indicated that in Sweden having highly educated adult children may enhance parents' health via the provision of valuable informational support for health-related behaviours, or help to navigate different treatment options and specialists within the health-care system. Hence after establishing whether there is an association between parent-child relative education and fathers' and mothers' longevity within the European context, our third objective is to assess whether mechanisms related to health behaviours (physical (in)activity) and health status (self-rated health) underlie any beneficial effect of having highly educated adult children for parents in early and later older age.

\section{Education as a family-level resource}

Previous research has demonstrated the importance of the education of significant others as an influence on an individual's mortality (Ross and Van Willigen, 1997). 
Resource pooling transforms an individual's education into a family-level resource (Smith and Zick, 1994). As a result, social relationships within, and outside, the household have the potential to create synergistic effects, including the promotion of health among older adults (Seeman, 2000; Marmot et al., 2003). In recent decades, literature on health inequalities has discussed how the education of significant others may affect an individual's mortality favourably via knowledge transmission, imitation of behaviour and economic support (Ross and Mirowsky, 1999). The educational composition of the family clearly matters for the health of individual family members, with past studies suggesting a 'spillover effect' from the education of partners (Monden et al., 2003; Huijts et al., 2010). Although it seems reasonable to assume that the influence of an individual's own education will remain pivotal (Huisman et al., 2005; Elo, 2009), a solely individualistic approach to the socioeconomic determinants of health among older adults ignores how families interact and influence one another in a multiplicity of ways (Ross et al., 1990). From this extended perspective, there is clearly potential for adult children to influence their parents' health significantly if the essential components of intergenerational solidarity - including affection, association, consensus, resource sharing and the opportunity structure for interaction - are in place during the adult family lifecourse (Bengtson and Roberts, 1991).

Within this context, while several earlier studies have demonstrated a relationship between an individual's mortality and the quantity of children he or she has, with childless individuals having higher mortality than those with children (Kendig et al., 2007; Christiansen, 2014; Modig et al., 2017), the relationship between an individual's mortality and the quality of children in terms of their educational attainment is only just beginning to emerge. The first studies to examine the association between adult children's education and parents' health and mortality were undertaken in non-Western contexts (Zimmer et al., 2002, 2007). Zimmer et al. (2002) found that, in Taiwan, the level of education of an adult child was positively associated with older parents' greater physical functioning, and negatively associated with the mortality of their elderly parents, particularly among parents who already had severe health problems at the start of the mortality follow-up (Zimmer et al., 2007). While various later studies have also demonstrated an association between an individual's mortality and the quality of children in terms of their educational attainment, a growing share of this work has primarily focused on low- and middle-income countries (Zimmer et al., 2002, 2007; Yahirun et al., 2016, 2017; Yang et al., 2016; De Neve and Harling, 2017; Smith-Greenaway et al., 2018). As recently noted (De Neve and Kawachi, 2017), one reason for the dearth of research in high-income contexts may be the expectation that the influence of adult children on parental health is likely to be less pronounced in countries with developed welfare systems providing for the vulnerable and elderly.

Nevertheless, a few recent studies from North America and Europe have reported a protective association between adult children's education and parental health (Torssander, 2013, 2014; Friedman and Mare, 2014; Zimmer et al., 2016; Elo et al., 2018). Friedman and Mare's (2014) work in the USA showed that parents of well-educated children live longer than do other parents, even after controlling for parents' own socio-economic resources. Similarly, research in Sweden indicated that parents' mortality cannot be fully explained by their own socio-economic 
resources or those of their partners (Torssander, 2013), and identified net associations between children's various socio-economic resources (education, occupation and income) and parents' mortality risk, with the clearest association for education (Torssander, 2014). Using a large Utah-based multigenerational data resource and a network approach to health determinants, the recent study by Zimmer et al. (2016) supports the existence of a longevity penalty for parents whose adult children have low socio-economic status and a longevity dividend for those whose adult children have a high socio-economic position, albeit the effects of adult children's education are attenuated by parental age. In a similar vein, Elo et al. (2018), using register data from Finland, have deepened our understanding by showing that higher levels of children's education are associated with lower parental mortality at ages 50-74, an association that becomes much weaker at 75 and over. Their study also confirmed that children's education remains more strongly associated with mortality than children's occupation or income.

Less is known about how children's education might influence their parents' health. One possibility is through the communication of advice and encouragement. Higher levels of children's education are associated with increased parent-child communication (Cutler and Lleras-Muney, 2010), and enhanced communication could include health advice and the encouragement of a healthy lifestyle. The latter seems particularly relevant due to the higher prevalence of unhealthy behaviours among individuals in lower socio-economic positions (Lakka et al., 1996; Lynch et al., 1997), which is one of the main factors linked to poor health (Schrijvers et al., 1999; Stringhini et al., 2010). Evidence from past studies in low- and middle-income countries suggests that the expansion of education through compulsory schooling provides parents with greater resources to rely on through the education of their children. Such resources are associated with parents' lower exposure to health risks (e.g. smoking and alcohol use) and greater receipt of support (Smith-Greenaway et al., 2018), and are found to predict parents' physical limitations (Zimmer et al., 2002; Yahirun et al., 2016). Although recent evidence also indicates that adult children's education is not necessarily associated with short-term changes in parents' physical functioning in the Mexican context, it is nonetheless associated with increased parents' longevity (Yahirun et al., 2017). Other previous studies from high-income countries have indicated that adult children with additional education or health knowledge promote physical activity among their parents (Berniell et al., 2013), and that parents who receive social support from their adult children tend to engage more frequently in active exercise (Thomas et al., 2019), motivated by a desire to maintain health and longevity for their children (Reczek et al., 2014). Further, parents with highly educated children are less likely to experience depressive symptoms (Sabater and Graham, $2016 a$ ), which in turn is associated with higher levels of physical activity (Umberson et al., 2008). This empirical evidence suggests that having highly educated adult children allows parents access to more and better quality resources (e.g. social, psychological or material) to avoid unhealthy behaviours and adopt effective coping strategies. It also highlights what was already recognised by social exchange theory (Astone et al., 1999), namely that social support provided by adult children has long been found beneficial for parental health in virtually all societies.

Theories concerning the relationships between social networks and health suggest various other pathways through which social contacts may influence health 
(Berkman and Glass, 2000). According to Torssander (2013: 638), 'three of these pathways are potentially relevant for child-to-parent transmission: provision of social support, social influence, and access to resources'. Upward health transfers within the family may involve both direct and indirect effects (Friedman and Mare, 2014). In other words, while children may directly affect parents' health by consciously providing better access to information and care that improves their parents' health, they may also affect their parents' health through health 'spillovers' or 'contagion effects'. In practical terms, the latter means that parents' exposure to well-educated children's health behaviours and lifestyles may influence them to adopt healthier behaviour themselves without explicit intervention from their children. Nevertheless, there remains a need for a greater understanding of the ways that family ties shape parental health (Umberson et al., 2010).

In sum, although the advantages of having children with important resources extend beyond the health benefits to parents, explanations that are directly related to the value of education for health are possible and may constitute a core component of family support in the broader context of intergenerational exchanges. These potential pathways of upward intergenerational transfers underpin the main focus of our analysis, which examines whether the mortality gradient among older parents is modified depending on the relative education of fathers/mothers and their adult children.

\section{Research questions}

Building on and extending previous work, this study addresses three key research questions:

- Research question 1: Is having highly educated adult children associated with lower mortality risks for father and mothers with low educational attainment in the European context?

Answering this initial question using Europe-wide comparable longitudinal data provides a starting point for further analysis. Our purpose is to establish whether there is a statistical association between the relative educational attainment of parent and child and the longevity of older parents, net of other relevant factors. Given the enduring longevity differentials between men and women, separate analyses are conducted for fathers and mothers.

- Research question 2: Do any such relationships differ for fathers and mothers in early (ages 50-74) and later (ages 75 and over) older age?

Next we examine when in the older lifecourse educational differences between the younger and older generations matter most for parental longevity. Since health inequalities might be more pronounced in the earlier stages of later life such as at retirement, when socio-economic disadvantaged individuals are more likely to retire for health reasons, it seems reasonable to expect that having highly educated children is most likely to have a positive effect on the health of parents during early older age. In contrast, since educational differences in health may decrease at older 
ages, it seems reasonable to expect that having highly educated children might be less relevant in old age because of general health decline, as well as mortality selection. However, if educational differences in health are assumed to increase with age, the benefits of having highly educated children on the health of parents might also be apparent during later older age. Thus, in order to complement the growing literature concerning upward health transfers, our analyses consider the benefits of adult children's education relative to the level of education of their parents for respondents in two age groups (50-74 and 75+). This consideration is important as most previous studies, with the exceptions of Zimmer et al. (2016) and Elo et al. (2018), do not differentiate among older age groups despite age being significantly associated with a higher risk of dying.

- Research question 3: Are the associations between having highly educated adult children and the mortality risks of fathers and mothers (partly) explained by parents' health behaviour and health status?

Lastly, we begin to tackle the complex question of how highly educated children might positively influence the health of parents with different levels of educational attainment. We adopt two different approaches to examine potential mechanisms through which adult children's education may influence parents' health. First, we assess whether the estimated effect of parent-child relative education on parents' survival is attenuated when information closely linked to health behaviours (physical (in)activity) and health status (self-reported health) is included in the analysis. Measures of (lack of) physical exercise are useful indicators to assess health among older people (Peralta et al., 2017) and, to our knowledge, only one previous study (Friedman and Mare, 2014) has examined exercise behaviours to see whether these constitute a plausible pathway for upward health transfers from adult children to their parents. In addition, measures of overall health are often regarded as surprisingly strong and robust predictors of mortality, even after controlling for many medical and behavioural risk factors (Lima-Costa et al., 2011). Thus, our second approach investigates whether the relative education of adult children and their parents is associated with the parents' longevity and assess these relations in samples of respondents stratified by overall health status. As shown by Zimmer et al. (2007), this type of analysis allows us to examine whether having highly educated adult children may enhance prevention of health conditions (among parents in good health) or may influence the recovery after the onset of illness (among parents in poor health).

\section{Data and method}

\section{Data}

Our analyses employ high-quality survey data from the initial five waves of SHARE, a prospective observational study of non-institutionalised people aged 50 years and over (for a detailed description, see Börsch-Supan et al., 2013 and http://www. share-project.org/).

We use SHARE data from the baseline study in 2004, with follow-up interviews in 2006, 2010, 2013 and 2015, thus including longitudinal information from the 11 
European countries that first contributed to the 2004 SHARE baseline study, and that have also taken part in subsequent waves since then (Austria, Belgium, Denmark, France, Germany, Greece, Italy, Spain, Sweden, Switzerland and The Netherlands). The availability of information on the respondent's own socioeconomic status and, crucially, the educational attainment of their adult children, makes SHARE a valuable data-set for examining the relationship between adult children's education and parental longevity.

\section{Study population}

Our analytical sample comprises 15,015 individuals, after the exclusion of respondents without adult children $(\mathrm{N}=2,552)$ and respondents whose adult children were aged under 25 years $(\mathrm{N}=1,423)$. We take 25 as the lower age limit because stability in educational attainment generally occurs from this age onwards. Following previous studies (Elo et al., 2018), we estimate separate models for fathers $(\mathrm{N}=6,620)$ and mothers $(\mathrm{N}=8,395)$.

\section{Outcome: parental deaths}

All deaths $(\mathrm{N}=1,847)$ in the second and subsequent waves of SHARE were registered in end-of-life interviews using personal identification numbers, and recorded by month and cause of death. Attrition from the panel is likely to affect the number of deaths and may result in an underestimation of mortality in SHARE's mortality follow-up (Schulz and Doblhammer, 2010). Analyses of survey participation in SHARE have revealed that only the oldest-old show a higher probability of nonresponse (Kneip et al., 2015), which indicates that attrition at these ages might indeed be a problem of mortality rather than refusal to participate. We excluded participants $(\mathrm{N}=2)$ who died in the same month they granted their baseline interview. Since small sample sizes present difficulties for the analysis of cause-specific hazards of mortality, we use all-cause mortality as the main outcome in this study.

\section{Parent and adult children's education}

To examine the association between parent-child relative education and fathers' and mothers' longevity, including whether adult children's education has a stronger influence on the longevity of older parents who have lower educational attainment than their children, we devised a measure of relative education. Two categories were used for parents (compulsory and post-compulsory education) and three categories for adult children (compulsory or primary/lower secondary, upper secondary and tertiary education) from the ISCED (International Standard Classification of Education), creating a six-category interaction measure of 'relative education' in which these two categorical variables are multiplied. The resulting interaction term constitutes a meaningful predictor for examining whether the effect of adult children's education on the outcome (parental death from all causes) varies for different levels of parental education. We use a categorical specification of education for predicting mortality following previous research indicating a better model fit compared to a continuous specification (Backlund et al., 1999). 
As most families have more than one child, preliminary analyses considered and compared several constructions of adult children's education, including (a) whether any child has tertiary education, (b) the average and median years of educational attainment of all children, and (c) the oldest, most educated child, aged at least 25 . We ran models with each of these specifications and found that the three constructions of education fit the data equally well. Following a 'dominance' approach specified in Torssander (2014), we selected for our measure the child with the highest level of educational attainment and, where there was more than one child with similar levels of education, the oldest. Implementation of the dominance approach not only considers the highest level of education but also the dominant position. In all such cases, we assume that the health of an older parent is influenced most by the oldest child with the highest level of education as she or he is likely to have the greatest availability of resources, including health knowledge. The latter is also consistent with the notion that there is a larger benefit from the first daughter or son than from later children (Christiansen, 2014).

\section{Socio-economic covariates}

Model covariates include three additional, time-varying measures of socioeconomic status: household income, household wealth and spouse's educational attainment. Household income is defined by the annual earnings of all household members, whereas household wealth (total net worth) measures the sum of all financial (net stock value, mutual funds, bonds and savings) and housing wealth (value of primary residence net of mortgage, other real estate value, owned business share and owned cars) minus liabilities. Income and wealth data are specified in terms of purchasing power parity (PPP), which includes conversion into euros and corrections for differences in purchasing power across the survey countries. Following previous studies (Hairi et al., 2010), we divided income and wealth by the square root of the number of household members to account for household size. Among the 15,015 individuals with baseline data, only 188 cases did not have complete data on model variables (1.25\%). To maximise the size of the useable sample, we imputed these data using the Stata multiple imputation suite.

\section{Statistical analysis}

Our modelling strategy follows that of Friedman and Mare (2014), although our focus is on the effect of the relative educational attainment of fathers or mothers and their adult children on the all-cause mortality of parents. Thus, Cox proportional hazard regression models are fitted first with the interaction measure of parent-child relative education (Model 1). We then account for marital status and partner's educational attainment (Model 2) and lastly for respondents' household income and household wealth (Model 3). Our approach builds upon previous analyses in which the mortality of parents was examined with main effects only (using parents' education and adult children's education) as well as with parent-child interactions of educational attainment with and without main effects (Sabater and Graham, 2016b). Based on model fit tests, in this paper we only provide results from the statistical analysis of the interaction term that is under investigation 
(i.e. without main effects). Since the presence of a high-order interaction renders the estimates for lower-order terms meaningless (as their effects are absorbed by the interaction), the approach used in the current study has the advantage of capturing the value of the interaction without the interference of low-order effects. Hazard ratios (HR) from Cox models predicting risk of death are reported in all tables and we present only the results for our key variable. ${ }^{1}$ Since spouses of respondents were also interviewed, robust standard errors are estimated to adjust for clustering of respondents within households.

Survival time is measured as the amount of time that elapsed between the date of baseline interview and death, or censoring resulting from non-response or the end of the study period. Mortality risks are estimated based on verified deaths, otherwise the respondents are assumed to have survived until the end of the observation period. Our unit of analysis is the individual parent (father or mother). Analyses are performed first with all older parents combined and then separately for those in early older age (50-74) and later older age (75 years and over). Because respondents are fathers and mothers from 11 European countries, we allow the baseline hazards to vary by sex of parent and country of residence. We thus relax the assumption that the combined effects of education and other covariates are the same for all countries under consideration. This is important to prevent bias arising from non-proportionality in the survival curves.

Cox regression models are also employed to test whether at least part of the association between the relative educational attainment of parents and their adult children (our interaction measure) and the parents' all-cause mortality is explained by parents' physical (in)activity and overall health. Using a measure related to lack of exercise is appropriate because it captures a negative behaviour and a major cause of chronic diseases (Booth et al., 2012). Further, the use of a standard measure of self-rated health has the advantage of capturing subtle aspects of health, including diseases that exist but are unreported, and psycho-social factors that may also relate to survival. Self-rated health was measured using the European version of subjective health status (very good, good, fair, bad or very bad).

\section{Results}

Table 1 provides a descriptive analysis of the characteristics of the total sample (i.e. all parents), and of fathers and mothers separately, at baseline. Fathers constitute 44 per cent and mothers 56 per cent of the total sample of parents. The majority of parents are married, although over one-third (34.6\%) are widowed mothers, and the mean number of children present for all parents is 2.5 , with most parents having, at least, two adult children who could provide support. Importantly, almost 50 per cent of fathers and over 60 per cent of mothers only have compulsory education.

However, as Table 2 shows, it is also very possible for fathers and mothers with low education to have adult children with upper secondary or tertiary levels of education. The cross-tabulation of parents' own education by adult children's education shows that, in addition to similar levels of education between parents and their adult children, there is also a widespread distribution of respondents (mothers and fathers) with children who have different levels of education. For instance, of 
Table 1. Sample characteristics of parents at baseline

\begin{tabular}{|c|c|c|c|c|c|c|}
\hline & \multicolumn{2}{|c|}{ Entire sample } & \multicolumn{2}{|c|}{ Fathers } & \multicolumn{2}{|c|}{ Mothers } \\
\hline & Mean or $\mathrm{N}$ & SD or $\%$ & Mean or $\mathrm{N}$ & SD or $\%$ & Mean or $\mathrm{N}$ & SD or $\%$ \\
\hline Mean age (SD) & 66.3 & 10.2 & 66.0 & 9.7 & 66.5 & 10.6 \\
\hline \multicolumn{7}{|l|}{ Foreign-born: } \\
\hline No & 13,820 & 92.0 & 6,096 & 92.1 & 7,724 & 92.0 \\
\hline Yes & 1,195 & 8.0 & 524 & 7.9 & 671 & 8.0 \\
\hline \multicolumn{7}{|l|}{ Education: } \\
\hline Compulsory & 8,297 & 55.3 & 3,145 & 47.5 & 5,152 & 61.4 \\
\hline Post-compulsory & 6,718 & 44.7 & 3,475 & 52.5 & 3,243 & 38.6 \\
\hline \multicolumn{7}{|l|}{ Physically inactive: } \\
\hline No & 13,386 & 89.2 & 6,101 & 92.2 & 7,285 & 86.8 \\
\hline Yes & 1,629 & 10.9 & 519 & 7.8 & 1,110 & 13.2 \\
\hline \multicolumn{7}{|l|}{ Self-rated health: } \\
\hline Very good & 2,593 & 17.3 & 1,298 & 19.6 & 1,295 & 15.4 \\
\hline Good & 6,395 & 42.6 & 2,933 & 44.3 & 3,462 & 41.2 \\
\hline Fair & 4,540 & 30.2 & 1,827 & 27.6 & 2,713 & 32.3 \\
\hline Bad & 1,179 & 7.9 & 440 & 6.7 & 739 & 8.8 \\
\hline Very bad & 308 & 2.1 & 122 & 1.8 & 186 & 2.2 \\
\hline \multicolumn{7}{|l|}{ Marital status: } \\
\hline Married/partnership & 9,810 & 65.3 & 5,391 & 81.4 & 4,419 & 52.6 \\
\hline Single/separated & 1,644 & 11.0 & 569 & 8.6 & 1,075 & 12.8 \\
\hline
\end{tabular}


Table 1. (Continued.)

\begin{tabular}{|c|c|c|c|c|c|c|}
\hline & \multicolumn{2}{|c|}{ Entire sample } & \multicolumn{2}{|c|}{ Fathers } & \multicolumn{2}{|c|}{ Mothers } \\
\hline \multicolumn{7}{|l|}{ Partner's education: } \\
\hline Compulsory & 8,390 & 55.9 & 3,657 & 55.2 & 4,733 & 56.4 \\
\hline Mean household wealth $(€, S D)$ & 190,000 & 410,000 & 220,000 & 400,000 & 170,000 & 420,000 \\
\hline Mean number of children (SD) & 2.5 & 1.3 & 2.5 & 1.3 & 2.5 & 1.3 \\
\hline Mean age of adult child (SD) & 40.7 & 10.1 & 39.0 & 9.4 & 42.0 & 10.5 \\
\hline \multicolumn{7}{|l|}{ Sex of adult child: } \\
\hline \multicolumn{7}{|l|}{ Children's education: } \\
\hline Compulsory & 3,213 & 21.4 & 1,272 & 19.2 & 1,941 & 23.1 \\
\hline Upper secondary & 6,435 & 42.9 & 2,863 & 43.3 & 3,572 & 42.6 \\
\hline Tertiary & 5,367 & 35.7 & 2,485 & 37.5 & 2,882 & 34.3 \\
\hline \multicolumn{7}{|l|}{ Parent-child proximity: } \\
\hline Closer than $100 \mathrm{~km}$ & 12,177 & 81.1 & 5,316 & 80.3 & 6,861 & 81.7 \\
\hline At least $100 \mathrm{~km}$ away & 2,838 & 18.9 & 1,304 & 19.7 & 1,534 & 18.3 \\
\hline$N$ & 15,015 & & 6,620 & & 8,395 & \\
\hline
\end{tabular}


Table 2. Parents' own education by adult children's education

\begin{tabular}{|c|c|c|c|c|}
\hline \multirow[b]{2}{*}{ Parents' education } & \multicolumn{3}{|c|}{ Adult children's education } & \multirow[b]{2}{*}{ Total } \\
\hline & Compulsory & Upper secondary & Tertiary & \\
\hline & \multicolumn{4}{|c|}{ Frequencies (\%) } \\
\hline \multicolumn{5}{|l|}{ Fathers - all ages: } \\
\hline \multirow[t]{2}{*}{ Compulsory } & 1,039 & 1,352 & 754 & 3,145 \\
\hline & $(33.0)$ & $(43.0)$ & $(24.0)$ & $(100.0)$ \\
\hline \multirow[t]{2}{*}{ Post-compulsory } & 233 & 1,511 & 1,731 & 3,475 \\
\hline & $(6.7)$ & $(43.5)$ & $(49.8)$ & $(100.0)$ \\
\hline \multirow[t]{2}{*}{ Total } & 1,272 & 2,863 & 2,485 & 6,620 \\
\hline & $(19.2)$ & $(43.3)$ & $(37.5)$ & $(100.0)$ \\
\hline \multicolumn{5}{|l|}{ Fathers - aged 50-74: } \\
\hline \multirow[t]{2}{*}{ Compulsory } & 703 & 1,057 & 555 & 2,315 \\
\hline & $(30.4)$ & $(45.7)$ & $(24.0)$ & $(100.0)$ \\
\hline \multirow[t]{2}{*}{ Post-compulsory } & 192 & 1,306 & 1,442 & 2,940 \\
\hline & $(6.5)$ & $(44.4)$ & $(49.1)$ & $(100.0)$ \\
\hline \multirow[t]{2}{*}{ Total } & 895 & 2,363 & 1,997 & 5,255 \\
\hline & $(17.0)$ & $(45.0)$ & $(38.0)$ & $(100.0)$ \\
\hline \multicolumn{5}{|l|}{ Fathers - aged 75+: } \\
\hline \multirow[t]{2}{*}{ Compulsory } & 336 & 295 & 199 & 830 \\
\hline & $(40.5)$ & $(35.5)$ & $(24.0)$ & $(100.0)$ \\
\hline \multirow[t]{2}{*}{ Post-compulsory } & 41 & 205 & 289 & 535 \\
\hline & $(7.7)$ & $(38.3)$ & $(54.0)$ & $(100.0)$ \\
\hline \multirow[t]{2}{*}{ Total } & 377 & 500 & 488 & 1,365 \\
\hline & $(27.6)$ & $(36.6)$ & $(35.8)$ & $(100.0)$ \\
\hline \multicolumn{5}{|l|}{ Mothers - all ages: } \\
\hline \multirow[t]{2}{*}{ Compulsory } & 1,725 & 2,195 & 1,232 & 5,152 \\
\hline & (33.5) & $(42.6)$ & $(23.9)$ & $(100.0)$ \\
\hline \multirow[t]{2}{*}{ Post-compulsory } & 216 & 1,377 & 1,650 & 3,243 \\
\hline & $(6.7)$ & $(42.5)$ & $(50.9)$ & $(100.0)$ \\
\hline \multirow[t]{2}{*}{ Total } & 1,941 & 3,572 & 2,882 & 8,395 \\
\hline & $(23.1)$ & $(42.6)$ & $(34.3)$ & $(100.0)$ \\
\hline \multicolumn{5}{|c|}{ Mothers - aged 50-74: } \\
\hline \multirow[t]{2}{*}{ Compulsory } & 1,059 & 1,601 & 857 & 3,517 \\
\hline & $(30.1)$ & $(45.5)$ & $(24.4)$ & $(100.0)$ \\
\hline Post-compulsory & 192 & 1,206 & 1,435 & 2,833 \\
\hline
\end{tabular}


Table 2. (Continued.)

\begin{tabular}{|ccccc}
\hline & \multicolumn{3}{c}{ Adult children's education } & \\
\cline { 2 - 4 } Parents' education & Compulsory & Upper secondary & Tertiary & Total \\
\hline & $(6.8)$ & $(42.6)$ & $(50.7)$ & $(100.0)$ \\
\hline Total & 1,251 & 2,807 & 2,292 & 6,350 \\
\hline Mothers - aged 75+: & $(19.7)$ & $(44.2)$ & $(36.1)$ & $(100.0)$ \\
\hline Compulsory & & & & \\
\hline Post-compulsory & 666 & 594 & 375 & 1,635 \\
\hline Total & $(40.7)$ & $(36.3)$ & $(22.9)$ & $(100.0)$ \\
\hline & 24 & 171 & 215 & 410 \\
\hline
\end{tabular}

fathers and mothers with only compulsory education, over two-fifths have an adult child with upper secondary education and over one-fifth have an adult child with tertiary education. This highlights educational differentials between parents and adult children in our sample, which indicates the presence of intergenerational educational mobility and, therefore, the possibility of highly educated adult children being a vehicle for parents' empowerment in terms of health, particularly among parents with low educational attainment. While one-third of fathers and mothers with only compulsory education have an adult child with similar levels of education, over two-fifths of fathers and mothers with post-compulsory levels of education have an adult child with upper secondary education and around a half have an adult child with tertiary education. These distributions support the idea that, in order to gain further understanding of the relationship between adult children's education and parents' longevity, it is important to model educational differences and similarities between parents and their adult children.

Table 3 presents the first set of results from Cox regressions. The models for 'all ages' predict the hazard of mortality for all fathers and mothers aged 50 and over, and confirm that having tertiary-educated adult children is associated with lower mortality risks for both fathers $(\mathrm{HR}=0.701,95 \%$ confidence interval $(\mathrm{CI})=$ $0.546-0.899, p<0.01)$ and mothers $(\mathrm{HR}=0.802,95 \% \mathrm{CI}=0.653-0.983, p<0.05)$ who have compulsory education, compared to the reference group whose adult children have only compulsory education. After controlling for marital status and partners' education (Model 2), the associations between parent-child relative education and fathers' and mothers' mortality risks persist, albeit slightly attenuated for mothers, thus indicating that parental longevity may be shaped by the combined effects of marital status and the relative educational attainment of parents and their children. Further adjusting for household income and household wealth (Model 3) decreases the strength of these associations, but having tertiary-educated 
Table 3. Relative education of parents and adult children predicting parental mortality risks for all ages (aged 50 and over), early older age (ages 50-74) and later older age (ages 75 and over)

\begin{tabular}{|c|c|c|c|c|}
\hline Parents' education & Children's education & Model 1 & Model 2 & Model 3 \\
\hline & & \multicolumn{3}{|c|}{ Hazard ratios (SE) } \\
\hline \multicolumn{5}{|l|}{ Fathers - all ages: } \\
\hline \multirow[t]{2}{*}{ Compulsory } & \multirow[t]{2}{*}{ Upper secondary } & 0.845 & $0.841^{\star}$ & 0.852 \\
\hline & & $(0.086)$ & $(0.086)$ & $(0.087)$ \\
\hline \multirow[t]{2}{*}{ Compulsory } & \multirow[t]{2}{*}{ Tertiary } & $0.701^{\star \star \star}$ & $0.700^{\star \star \star}$ & $0.715^{\star \star \star}$ \\
\hline & & $(0.089)$ & $(0.089)$ & $(0.091)$ \\
\hline \multirow[t]{2}{*}{ Post-compulsory } & \multirow[t]{2}{*}{ Compulsory } & 0.798 & 0.790 & 0.805 \\
\hline & & $(0.165)$ & $(0.163)$ & $(0.167)$ \\
\hline \multirow[t]{2}{*}{ Post-compulsory } & \multirow[t]{2}{*}{ Upper secondary } & $0.629^{\star \star \star}$ & $0.610^{\star \star \star}$ & $0.630^{\star \star \star}$ \\
\hline & & $(0.081)$ & $(0.079)$ & $(0.082)$ \\
\hline \multirow[t]{2}{*}{ Post-compulsory } & \multirow[t]{2}{*}{ Tertiary } & $0.644^{\star \star \star}$ & $0.630^{\star \star \star}$ & $0.654^{\star \star \star}$ \\
\hline & & $(0.079)$ & $(0.077)$ & $(0.081)$ \\
\hline AIC & & 10,383 & 10,376 & 10,376 \\
\hline $\mathrm{BIC}$ & & 10,457 & 10,471 & 10,485 \\
\hline Log-likelihood & & $-5,180$ & $-5,174$ & $-5,172$ \\
\hline \multicolumn{5}{|l|}{ Fathers - aged 50-74: } \\
\hline \multirow[t]{2}{*}{ Compulsory } & \multirow[t]{2}{*}{ Upper secondary } & $0.727^{\star \star}$ & $0.736^{\star}$ & $0.758^{\star}$ \\
\hline & & $(0.109)$ & $(0.110)$ & $(0.114)$ \\
\hline \multirow[t]{2}{*}{ Compulsory } & \multirow[t]{2}{*}{ Tertiary } & $0.530^{\star \star \star}$ & $0.542^{\star \star \star}$ & $0.561^{\star \star \star}$ \\
\hline & & $(0.112)$ & $(0.114)$ & $(0.118)$ \\
\hline \multirow[t]{2}{*}{ Post-compulsory } & \multirow[t]{2}{*}{ Compulsory } & 0.744 & 0.752 & 0.772 \\
\hline & & $(0.205)$ & $(0.206)$ & $(0.213)$ \\
\hline \multirow[t]{2}{*}{ Post-compulsory } & \multirow[t]{2}{*}{ Upper secondary } & $0.590^{\star \star \star}$ & $0.576^{\star \star \star}$ & $0.604^{\star \star \star}$ \\
\hline & & $(0.106)$ & $(0.104)$ & $(0.110)$ \\
\hline \multirow[t]{2}{*}{ Post-compulsory } & \multirow[t]{2}{*}{ Tertiary } & $0.543^{\star \star \star}$ & $0.543^{\star \star \star}$ & $0.577^{\star \star \star}$ \\
\hline & & $(0.098)$ & $(0.099)$ & $(0.105)$ \\
\hline AIC & & 4,926 & 4,920 & 4,915 \\
\hline $\mathrm{BIC}$ & & 4,999 & 5,012 & 5,020 \\
\hline Log-likelihood & & $-2,452$ & $-2,446$ & $-2,441$ \\
\hline \multicolumn{5}{|l|}{ Fathers - aged 75+: } \\
\hline \multirow[t]{2}{*}{ Compulsory } & \multirow[t]{2}{*}{ Upper secondary } & 0.926 & 0.931 & 0.934 \\
\hline & & $(0.124)$ & $(0.125)$ & $(0.126)$ \\
\hline Compulsory & Tertiary & 0.797 & 0.793 & 0.794 \\
\hline
\end{tabular}


Table 3. (Continued.)

\begin{tabular}{|c|c|c|c|c|}
\hline Parents' education & Children's education & Model 1 & Model 2 & Model 3 \\
\hline & & $(0.126)$ & $(0.125)$ & $(0.126)$ \\
\hline \multirow[t]{2}{*}{ Post-compulsory } & Compulsory & 0.661 & 0.663 & 0.674 \\
\hline & & $(0.219)$ & $(0.220)$ & $(0.225)$ \\
\hline \multirow[t]{2}{*}{ Post-compulsory } & Upper secondary & $0.632^{\star \star}$ & $0.621^{\star \star}$ & $0.633^{\star \star}$ \\
\hline & & $(0.116)$ & $(0.114)$ & (0.119) \\
\hline \multirow[t]{2}{*}{ Post-compulsory } & Tertiary & 0.773 & 0.759 & 0.776 \\
\hline & & $(0.124)$ & $(0.121)$ & $(0.127)$ \\
\hline AIC & & 4,236 & 4,238 & 4,241 \\
\hline $\mathrm{BIC}$ & & 4,293 & 4,311 & 4,324 \\
\hline Log-likelihood & & $-2,107$ & $-2,105$ & $-2,104$ \\
\hline \multicolumn{5}{|l|}{ Mothers - all ages: } \\
\hline \multirow[t]{2}{*}{ Compulsory } & Upper secondary & 0.941 & 0.945 & 0.947 \\
\hline & & $(0.083)$ & $(0.084)$ & $(0.084)$ \\
\hline \multirow[t]{2}{*}{ Compulsory } & Tertiary & $0.802^{\star \star}$ & $0.808^{\star \star}$ & $0.810^{\star \star}$ \\
\hline & & $(0.084)$ & $(0.085)$ & $(0.086)$ \\
\hline \multirow[t]{2}{*}{ Post-compulsory } & Compulsory & 0.689 & 0.689 & 0.691 \\
\hline & & $(0.183)$ & $(0.185)$ & $(0.186)$ \\
\hline \multirow[t]{2}{*}{ Post-compulsory } & Upper secondary & $0.682^{\star \star \star}$ & $0.687^{\star \star \star}$ & $0.689^{\star \star \star}$ \\
\hline & & $(0.096)$ & $(0.099)$ & $(0.100)$ \\
\hline \multirow[t]{2}{*}{ Post-compulsory } & Tertiary & $0.754^{\star \star}$ & $0.766^{\star \star}$ & $0.770^{\star}$ \\
\hline & & $(0.097)$ & $(0.102)$ & $(0.104)$ \\
\hline AIC & & 11,561 & 11,553 & 11,557 \\
\hline $\mathrm{BIC}$ & & 11,638 & 11,652 & 11,670 \\
\hline Log-likelihood & & $-5,769$ & $-5,763$ & $-5,762$ \\
\hline \multicolumn{5}{|c|}{ Mothers - aged 50-74: } \\
\hline \multirow[t]{2}{*}{ Compulsory } & Upper secondary & 0.854 & 0.855 & 0.884 \\
\hline & & $(0.131)$ & $(0.133)$ & $(0.138)$ \\
\hline \multirow[t]{2}{*}{ Compulsory } & Tertiary & $0.613^{\star \star}$ & $0.612^{\star \star}$ & $0.638^{\star *}$ \\
\hline & & $(0.123)$ & $(0.123)$ & $(0.130)$ \\
\hline \multirow[t]{2}{*}{ Post-compulsory } & Compulsory & 0.741 & 0.692 & 0.715 \\
\hline & & $(0.282)$ & $(0.267)$ & $(0.279)$ \\
\hline \multirow[t]{2}{*}{ Post-compulsory } & Upper secondary & 0.730 & $0.697^{\star}$ & 0.731 \\
\hline & & $(0.150)$ & $(0.147)$ & $(0.156)$ \\
\hline Post-compulsory & Tertiary & $0.624^{\star \star}$ & $0.605^{\star \star}$ & $0.651^{\star \star}$ \\
\hline
\end{tabular}


Table 3. (Continued.)

\begin{tabular}{|c|c|c|c|c|}
\hline Parents' education & Children's education & Model 1 & Model 2 & Model 3 \\
\hline & & $(0.126)$ & $(0.124)$ & $(0.139)$ \\
\hline AIC & & 4,010 & 4,006 & 4,005 \\
\hline $\mathrm{BIC}$ & & 4,084 & 4,100 & 4,113 \\
\hline Log-likelihood & & $-1,994$ & $-1,989$ & $-1,987$ \\
\hline \multicolumn{5}{|l|}{ Mothers - aged 75+: } \\
\hline \multirow[t]{2}{*}{ Compulsory } & \multirow[t]{2}{*}{ Upper secondary } & 1.008 & 1.018 & 1.010 \\
\hline & & $(0.105)$ & $(0.108)$ & $(0.107)$ \\
\hline \multirow[t]{2}{*}{ Compulsory } & \multirow[t]{2}{*}{ Tertiary } & 0.903 & 0.917 & 0.907 \\
\hline & & $(0.109)$ & $(0.111)$ & $(0.111)$ \\
\hline \multirow[t]{2}{*}{ Post-compulsory } & \multirow[t]{2}{*}{ Compulsory } & 0.661 & 0.692 & 0.674 \\
\hline & & $(0.246)$ & $(0.259)$ & $(0.252)$ \\
\hline \multirow[t]{2}{*}{ Post-compulsory } & \multirow[t]{2}{*}{ Upper secondary } & $0.600^{\star \star}$ & $0.640^{\star \star}$ & $0.632^{\star \star}$ \\
\hline & & $(0.124)$ & $(0.135)$ & $(0.133)$ \\
\hline \multirow[t]{2}{*}{ Post-compulsory } & \multirow[t]{2}{*}{ Tertiary } & 0.852 & 0.915 & 0.897 \\
\hline & & $(0.147)$ & $(0.163)$ & $(0.162)$ \\
\hline AIC & & 6,335 & 6,332 & 6,335 \\
\hline $\mathrm{BIC}$ & & 6,397 & 6,411 & 6,425 \\
\hline Log-likelihood & & $-3,157$ & $-3,152$ & $-3,151$ \\
\hline
\end{tabular}

Notes: Reference group is compulsory education for both parents and adult children. All models stratified by country of residence. Model 1: Adjusted for parents' age, country of birth and number of adult children, as well as age and sex of adult child, and parent-child geographical proximity. Model 2: As Model 1, plus adjustment for marital status and partners' education. Model 3: As Model 2, plus adjustment for household income and household wealth. SE: standard error. AIC: Akaike information criterion. BIC: Bayesian information criterion.

Significance levels: ${ }^{\star} p<0.1,{ }^{\star *} p<0.05,{ }^{\star * \star} p<0.01$.

adult children remains a significant predictor of lower mortality risks for fathers $(\mathrm{HR}=0.715,95 \% \mathrm{CI}=0.557-0.917, p<0.01)$ and mothers $(\mathrm{HR}=0.810,95 \% \mathrm{CI}$ $=0.658-0.997, p<0.05)$ who themselves have only compulsory education. Thus, our results support a positive answer to our first research question by confirming that having highly educated adult children is associated with a mortality benefit for parents with low educational attainment.

The results for all older parents indicate that having upper secondary/ tertiary-educated adult children also appears to be a significant predictor of lower mortality risks for fathers $(\mathrm{HR}=0.630,95 \% \mathrm{CI}=0.488-0.813, p<0.01$; $\mathrm{HR}$ $=0.654,95 \% \mathrm{CI}=0.514-0.833, p<0.01)$ and mothers $(\mathrm{HR}=0.689,95 \% \mathrm{CI}=$ 0.519-0.915, $p<0.01 ; \mathrm{HR}=0.770,95 \% \mathrm{CI}=0.591-1.004, p<0.1)$ who themselves have post-compulsory education, compared to the reference group of low-educated parents whose adult children have only compulsory education. In order to see whether there are significant differences among parents with post-compulsory education whose adult children have compulsory, upper secondary and tertiary 
education, we also changed the model specification by using the group of parents with post-compulsory education whose adult children have tertiary education as the reference group (see the Appendix). The results from this test for both fathers and mothers show that there are no statistically significant differences with regard to mortality risks among the group of parents with post-compulsory education whose adult children have different levels of education. This suggests that having highly educated children may not confer a mortality benefit on better-educated (post-compulsory) parents. However, these results also indicate that there are significant differences between the reference group and the group of parents who only have compulsory education, with the exception of those whose adult children have tertiary education. Thus, the test adds further evidence that having highly educated adult children is linked to a mortality advantage for parents with low educational attainment.

Since parental health may be more closely associated with age itself than with individual education, it is also interesting to examine the relationship between parent-child relative education and their parents' mortality risks for different parental age groups. Hence, the second set of results from Cox models (also in Table 3: 'aged 50-74' and 'aged 75+' sections) examine whether this mortality benefit differs according to the age of the parent. Our findings indicate that, compared to the reference group, having adult children with tertiary education reduces the risk of mortality for parents with compulsory (and post-compulsory) education in early older age but not in later older age. The largest health gains, as indicated by lower HR values (Table 3, Model 3), are found among parents aged 50-74 with lower education than their adult children (i.e. compulsory versus tertiary), where the association is statistically significant for both fathers $(\mathrm{HR}=0.561,95 \% \mathrm{CI}=0.371$ $0.847, p<0.01)$ and mothers $(\mathrm{HR}=0.638,95 \% \mathrm{CI}=0.428-0.951, p<0.05)$ who have only compulsory education. Among fathers and mothers aged 75 and over, the association only remains significant for well-educated fathers $(\mathrm{HR}=0.633$, $95 \% \mathrm{CI}=0.438-0.914, p<0.05)$ and mothers $(\mathrm{HR}=0.632,95 \% \mathrm{CI}=0.418-0.955$, $p<0.05)$ whose adult children have upper secondary education, compared to the reference group of low-educated parents whose adult children have only compulsory education.

To investigate possible pathways for upward health transfers, we fitted further Cox regressions (see Table 4) using the full specification (Model 3) from Table 3 but including separate adjustments for physical (in)activity (Model 4a) and overall health (Model 4b). After re-estimating the models with a control for lack of exercise, we observe that the magnitude of the coefficients from the original models is slightly reduced, thus providing some evidence that physical activity habits account for part of the relationship between the relative educational attainment of parents and children and parents' mortality risks, particularly for fathers in early older age and for mothers in both early and later older ages. The changes in the relationship between parent-child education and parents' longevity brought about by the inclusion of (lack of) physical activity suggest that at least part of the association between the relative educational attainment of parent and adult child and the survival of older fathers and mothers may be explained by parents' sedentary behaviour. As expected, however, controlling for parents' (lack of) physical activity does not fully explain the central relationship under consideration as 
Table 4. Relative education of parents and adult children predicting parental mortality risks for all ages (aged 50 and over), early older age (ages 50-74) and later older age (ages 75 and over) - net of (Model 4a) physical (in)activity and (Model $4 \mathrm{~b}$ ) self-rated health

\begin{tabular}{|c|c|c|c|c|}
\hline Parents' education & Children's education & Model 3 & Model 4a & Model $4 \mathrm{~b}$ \\
\hline & & \multicolumn{3}{|c|}{ Hazard ratios (SE) } \\
\hline \multicolumn{5}{|l|}{ Fathers - all ages: } \\
\hline \multirow[t]{2}{*}{ Compulsory } & \multirow[t]{2}{*}{ Upper secondary } & 0.852 & 0.862 & 0.872 \\
\hline & & $(0.089)$ & $(0.090)$ & $(0.090)$ \\
\hline \multirow[t]{2}{*}{ Compulsory } & \multirow[t]{2}{*}{ Tertiary } & $0.715^{\star \star \star}$ & $0.729^{* *}$ & $0.755^{\star *}$ \\
\hline & & $(0.093)$ & $(0.095)$ & $(0.097)$ \\
\hline \multirow[t]{2}{*}{ Post-compulsory } & \multirow[t]{2}{*}{ Compulsory } & 0.805 & 0.807 & 0.841 \\
\hline & & $(0.168)$ & $(0.167)$ & $(0.176)$ \\
\hline \multirow[t]{2}{*}{ Post-compulsory } & \multirow[t]{2}{*}{ Upper secondary } & $0.630^{\star \star \star}$ & $0.638^{\star \star \star}$ & $0.687^{\star \star \star}$ \\
\hline & & $(0.084)$ & $(0.089)$ & $(0.090)$ \\
\hline \multirow[t]{2}{*}{ Post-compulsory } & \multirow[t]{2}{*}{ Tertiary } & $0.654^{\star \star \star}$ & $0.664^{\star \star \star}$ & $0.728^{\star \star \star}$ \\
\hline & & $(0.083)$ & $(0.087)$ & $(0.091)$ \\
\hline AIC & & 10,376 & 10,370 & 10,319 \\
\hline $\mathrm{BIC}$ & & 10,485 & 10,485 & 10,455 \\
\hline Log-likelihood & & $-5,172$ & $-5,168$ & $-5,140$ \\
\hline \multicolumn{5}{|l|}{ Fathers - aged 50-74: } \\
\hline \multirow[t]{2}{*}{ Compulsory } & \multirow[t]{2}{*}{ Upper secondary } & $0.758^{\star}$ & 0.781 & 0.813 \\
\hline & & $(0.117)$ & $(0.123)$ & $(0.123)$ \\
\hline \multirow[t]{2}{*}{ Compulsory } & \multirow[t]{2}{*}{ Tertiary } & $0.561^{\star \star \star}$ & $0.601^{\star \star}$ & $0.667^{\star}$ \\
\hline & & $(0.128)$ & $(0.128)$ & $(0.140)$ \\
\hline \multirow[t]{2}{*}{ Post-compulsory } & \multirow[t]{2}{*}{ Compulsory } & 0.772 & 0.844 & 0.848 \\
\hline & & $(0.233)$ & $(0.221)$ & $(0.231)$ \\
\hline \multirow[t]{2}{*}{ Post-compulsory } & \multirow[t]{2}{*}{ Upper secondary } & $0.604^{\star \star \star}$ & $0.636^{\star \star}$ & $0.706^{\star}$ \\
\hline & & $(0.114)$ & $(0.123)$ & $(0.128)$ \\
\hline \multirow[t]{2}{*}{ Post-compulsory } & \multirow[t]{2}{*}{ Tertiary } & $0.577^{\star \star \star}$ & $0.612^{* *}$ & $0.697^{\star *}$ \\
\hline & & $(0.112)$ & $(0.120)$ & $(0.128)$ \\
\hline AIC & & 4,915 & 4,879 & 4,834 \\
\hline $\mathrm{BIC}$ & & 5,020 & 4,991 & 4,965 \\
\hline Log-likelihood & & $-2,441$ & $-2,422$ & $-2,397$ \\
\hline \multicolumn{5}{|l|}{ Fathers - aged 75+: } \\
\hline \multirow[t]{2}{*}{ Compulsory } & \multirow[t]{2}{*}{ Upper secondary } & 0.934 & 0.937 & 0.941 \\
\hline & & $(0.126)$ & $(0.124)$ & $(0.127)$ \\
\hline Compulsory & Tertiary & 0.794 & 0.799 & 0.782 \\
\hline
\end{tabular}


Table 4. (Continued.)

\begin{tabular}{|c|c|c|c|c|}
\hline Parents' education & Children's education & Model 3 & Model $4 a$ & Model $4 \mathrm{~b}$ \\
\hline & & $(0.127)$ & $(0.129)$ & $(0.125)$ \\
\hline \multirow[t]{2}{*}{ Post-compulsory } & Compulsory & 0.674 & 0.665 & 0.679 \\
\hline & & $(0.224)$ & $(0.222)$ & $(0.228)$ \\
\hline \multirow[t]{2}{*}{ Post-compulsory } & Upper secondary & $0.633^{\star \star}$ & $0.635^{\star \star}$ & $0.649^{\star \star}$ \\
\hline & & $(0.119)$ & $(0.127)$ & $(0.121)$ \\
\hline \multirow[t]{2}{*}{ Post-compulsory } & Tertiary & 0.776 & 0.779 & 0.781 \\
\hline & & $(0.128)$ & $(0.135)$ & $(0.130)$ \\
\hline AIC & & 4,241 & 4,242 & 4,242 \\
\hline $\mathrm{BIC}$ & & 4,324 & 4,331 & 4,346 \\
\hline Log-likelihood & & $-2,104$ & $-2,104$ & $-2,101$ \\
\hline \multicolumn{5}{|l|}{ Mothers - all ages: } \\
\hline \multirow[t]{2}{*}{ Compulsory } & Upper secondary & 0.947 & 0.952 & 0.994 \\
\hline & & $(0.085)$ & $(0.093)$ & (0.089) \\
\hline \multirow[t]{2}{*}{ Compulsory } & Tertiary & $0.810^{\star \star}$ & 0.830 & 0.880 \\
\hline & & $(0.088)$ & $(0.096)$ & $(0.094)$ \\
\hline \multirow[t]{2}{*}{ Post-compulsory } & Compulsory & 0.691 & 0.695 & 0.756 \\
\hline & & $(0.186)$ & $(0.203)$ & $(0.204)$ \\
\hline \multirow[t]{2}{*}{ Post-compulsory } & Upper secondary & $0.689^{\star \star \star}$ & $0.712^{\star}$ & $0.785^{\star}$ \\
\hline & & $(0.104)$ & $(0.114)$ & $(0.114)$ \\
\hline \multirow[t]{2}{*}{ Post-compulsory } & Tertiary & $0.770^{\star}$ & 0.785 & 0.888 \\
\hline & & $(0.107)$ & $(0.123)$ & $(0.121)$ \\
\hline AIC & & 11,557 & 11,546 & 11,528 \\
\hline $\mathrm{BIC}$ & & 11,670 & 11,666 & 11,669 \\
\hline Log-likelihood & & $-5,762$ & $-5,756$ & $-5,744$ \\
\hline \multicolumn{5}{|c|}{ Mothers - aged 50-74: } \\
\hline \multirow[t]{2}{*}{ Compulsory } & Upper secondary & 0.884 & 0.891 & 0.943 \\
\hline & & $(0.139)$ & $(0.153)$ & $(0.147)$ \\
\hline \multirow[t]{2}{*}{ Compulsory } & Tertiary & $0.638^{\star \star}$ & $0.656^{\star}$ & $0.684^{*}$ \\
\hline & & $(0.134)$ & $(0.139)$ & $(0.141)$ \\
\hline \multirow[t]{2}{*}{ Post-compulsory } & Compulsory & 0.715 & 0.715 & 0.785 \\
\hline & & $(0.280)$ & $(0.317)$ & $(0.307)$ \\
\hline \multirow[t]{2}{*}{ Post-compulsory } & Upper secondary & 0.731 & 0.757 & 0.828 \\
\hline & & $(0.163)$ & $(0.187)$ & $(0.178)$ \\
\hline \multirow[t]{2}{*}{ Post-compulsory } & Tertiary & $0.651^{\star \star}$ & 0.668 & 0.807 \\
\hline & & $(0.143)$ & $(0.167)$ & $(0.169)$ \\
\hline
\end{tabular}


Table 4. (Continued.)

\begin{tabular}{|ccccc}
\hline Parents' education & Children's education & Model 3 & Model 4a & Model 4b \\
\hline AIC & & 4,005 & 3,998 & 3,978 \\
\hline BIC & 4,113 & 4,113 & 4,113 \\
\hline Log-likelihood & $-1,987$ & $-1,982$ & $-1,969$ \\
\hline Mothers - aged 75+: & & & \\
\hline Compulsory & Upper secondary & 1.010 & 1.010 & 1.046 \\
\hline Compulsory & & $(0.107)$ & $(0.116)$ & $(0.111)$ \\
\hline Post-compulsory & Tertiary & 0.907 & 0.926 & 0.984 \\
\hline Post-compulsory & Upper secondary & $(0.113)$ & $(0.123)$ & $(0.122)$ \\
\hline Post-compulsory & Tertiary & 0.674 & 0.679 & 0.729 \\
\hline AIC & $(0.252)$ & $(0.258)$ & $(0.270)$ \\
\hline BIC & $0.632^{\star *}$ & $0.661^{*}$ & 0.719 \\
\hline Log-likelihood & & $(0.141)$ & $(0.144)$ & $(0.150)$ \\
\hline
\end{tabular}

Notes: Reference group is compulsory education for both parents and adult children. All models stratified by country of residence. SE: standard error. AIC: Akaike information criterion. BIC: Bayesian information criterion.

Significance levels: ${ }^{\star} p<0.1,{ }^{\star \star} p<0.05,{ }^{\star \star \star} p<0.01$.

there are many other health-related factors that are also likely to influence parent's longevity. To complement this analysis, Table 4 also displays results from Cox models which allow a more general evaluation of parents' health status using selfrated health. Comparing the results we see that the inclusion of self-rated health considerably attenuates the magnitude of the coefficients for each category of educational difference between parents and adult children. The largest reductions in the coefficients are found among fathers in early older age with both compulsory and post-compulsory education whose adult children have tertiary education. The results for mothers also highlight a mitigation of the association with the inclusion of this adjustment, reducing most coefficients to insignificance, and with the largest reductions found among mothers in later older age.

To gain further insight into whether adult children's education has different effects depending on the initial health status of father and mothers, we conducted an additional analysis based on the sample stratified by whether parents reported 'good' or 'very good' health, as opposed to 'very bad', 'bad' or 'fair' health at baseline (see Table 5). The results reveal that adult children's education is not significantly associated with parents' mortality risks when fathers and mothers' self-rated health appears to be 'good' or 'very good'. In contrast, adult children's 
Table 5. Relative education of parents and adult children predicting parental mortality risks for all ages (aged 50 and over), early older age (ages 50-74) and later older age (ages 75 and over) by self-rated health status

\begin{tabular}{|c|c|c|c|}
\hline \multirow[b]{2}{*}{ Parents' education } & \multirow[b]{2}{*}{ Children's education } & \multicolumn{2}{|c|}{ Self-rated health } \\
\hline & & Good to very good & Fair to very bad \\
\hline & & \multicolumn{2}{|c|}{ Hazard ratios (SE) } \\
\hline \multicolumn{4}{|l|}{ Fathers - all ages: } \\
\hline \multirow[t]{2}{*}{ Compulsory } & Upper secondary & 0.895 & 0.830 \\
\hline & & $(0.153)$ & $(0.103)$ \\
\hline \multirow[t]{2}{*}{ Compulsory } & Tertiary & 0.902 & $0.633^{\star \star \star}$ \\
\hline & & $(0.179)$ & $(0.106)$ \\
\hline \multirow[t]{2}{*}{ Post-compulsory } & Compulsory & 0.931 & 0.659 \\
\hline & & $(0.288)$ & $(0.195)$ \\
\hline \multirow[t]{2}{*}{ Post-compulsory } & Upper secondary & 0.977 & $0.520^{\star \star \star}$ \\
\hline & & $(0.190)$ & $(0.091)$ \\
\hline \multirow[t]{2}{*}{ Post-compulsory } & Tertiary & $0.722^{*}$ & 0.796 \\
\hline & & $(0.136)$ & $(0.127)$ \\
\hline $\mathrm{AIC}$ & & 4,111 & 5,024 \\
\hline $\mathrm{BIC}$ & & 4,212 & 5,116 \\
\hline Log-likelihood & & $-2,039$ & $-2,496$ \\
\hline \multicolumn{4}{|l|}{ Fathers - aged 50-74: } \\
\hline \multirow[t]{2}{*}{ Compulsory } & Upper secondary & 0.751 & 0.772 \\
\hline & & $(0.196)$ & $(0.140)$ \\
\hline \multirow[t]{2}{*}{ Compulsory } & Tertiary & 0.617 & $0.577^{\star \star}$ \\
\hline & & $(0.205)$ & $(0.157)$ \\
\hline \multirow[t]{2}{*}{ Post-compulsory } & Compulsory & 0.924 & 0.613 \\
\hline & & $(0.392)$ & $(0.241)$ \\
\hline \multirow[t]{2}{*}{ Post-compulsory } & Upper secondary & 0.952 & $0.489^{\star \star \star}$ \\
\hline & & $(0.258)$ & $(0.123)$ \\
\hline \multirow[t]{2}{*}{ Post-compulsory } & Tertiary & 0.644 & 0.743 \\
\hline & & $(0.185)$ & $(0.174)$ \\
\hline AIC & & 1,980 & 2,315 \\
\hline $\mathrm{BIC}$ & & 2,079 & 2,402 \\
\hline Log-likelihood & & -974 & $-1,142$ \\
\hline \multicolumn{4}{|l|}{ Fathers - aged 75+: } \\
\hline \multirow[t]{2}{*}{ Compulsory } & Upper secondary & 1.055 & 0.904 \\
\hline & & $(0.231)$ & $(0.153)$ \\
\hline
\end{tabular}


Table 5. (Continued.)

\begin{tabular}{|c|c|c|c|}
\hline \multirow[b]{2}{*}{ Parents' education } & \multirow[b]{2}{*}{ Children's education } & \multicolumn{2}{|c|}{ Self-rated health } \\
\hline & & Good to very good & Fair to very bad \\
\hline \multirow[t]{2}{*}{ Compulsory } & Tertiary & 1.175 & $0.662^{\star}$ \\
\hline & & $(0.294)$ & $(0.145)$ \\
\hline \multirow[t]{2}{*}{ Post-compulsory } & Compulsory & 0.908 & 0.493 \\
\hline & & $(0.417)$ & $(0.260)$ \\
\hline \multirow[t]{2}{*}{ Post-compulsory } & Upper secondary & 1.010 & $0.526^{\star \star \star}$ \\
\hline & & $(0.291)$ & $(0.131)$ \\
\hline \multirow[t]{2}{*}{ Post-compulsory } & Tertiary & 0.996 & 0.837 \\
\hline & & $(0.251)$ & $(0.188)$ \\
\hline $\mathrm{AIC}$ & & 1,615 & 2,041 \\
\hline $\mathrm{BIC}$ & & 1,687 & 2,114 \\
\hline Log-likelihood & & -791 & $-1,005$ \\
\hline \multicolumn{4}{|l|}{ Mothers - all ages: } \\
\hline \multirow[t]{2}{*}{ Compulsory } & Upper secondary & 1.079 & 0.959 \\
\hline & & $(0.171)$ & $(0.104)$ \\
\hline \multirow[t]{2}{*}{ Compulsory } & Tertiary & 0.872 & 0.842 \\
\hline & & $(0.163)$ & $(0.110)$ \\
\hline \multirow[t]{2}{*}{ Post-compulsory } & Compulsory & 0.893 & 0.607 \\
\hline & & $(0.332)$ & $(0.245)$ \\
\hline \multirow[t]{2}{*}{ Post-compulsory } & Upper secondary & 0.839 & $0.677^{\star}$ \\
\hline & & $(0.179)$ & $(0.141)$ \\
\hline \multirow[t]{2}{*}{ Post-compulsory } & Tertiary & 0.889 & 0.873 \\
\hline & & $(0.184)$ & $(0.159)$ \\
\hline AIC & & 3,848 & 6,476 \\
\hline $\mathrm{BIC}$ & & 3,951 & 6,575 \\
\hline Log-likelihood & & $-1,908$ & $-3,222$ \\
\hline \multicolumn{4}{|c|}{ Mothers - aged 50-74: } \\
\hline \multirow[t]{2}{*}{ Compulsory } & Upper secondary & 1.106 & 0.848 \\
\hline & & $(0.296)$ & $(0.168)$ \\
\hline \multirow[t]{2}{*}{ Compulsory } & Tertiary & 0.802 & $0.577^{\star \star}$ \\
\hline & & $(0.271)$ & $(0.156)$ \\
\hline \multirow[t]{2}{*}{ Post-compulsory } & Compulsory & 0.893 & 0.717 \\
\hline & & $(0.576)$ & $(0.362)$ \\
\hline
\end{tabular}


Table 5. (Continued.)

\begin{tabular}{|c|c|c|c|}
\hline \multirow[b]{2}{*}{ Parents' education } & \multirow[b]{2}{*}{ Children's education } & \multicolumn{2}{|c|}{ Self-rated health } \\
\hline & & Good to very good & Fair to very bad \\
\hline \multirow[t]{2}{*}{ Post-compulsory } & Upper secondary & 0.945 & 0.762 \\
\hline & & $(0.308)$ & $(0.225)$ \\
\hline \multirow[t]{2}{*}{ Post-compulsory } & Tertiary & 0.936 & 0.689 \\
\hline & & $(0.306)$ & $(0.200)$ \\
\hline AIC & & 1,611 & 1,961 \\
\hline $\mathrm{BIC}$ & & 1,712 & 2,053 \\
\hline Log-likelihood & & -790 & -964 \\
\hline \multicolumn{4}{|l|}{ Mothers - aged 75+: } \\
\hline \multirow[t]{2}{*}{ Compulsory } & Upper secondary & 1.069 & 1.060 \\
\hline & & $(0.204)$ & $(0.137)$ \\
\hline \multirow[t]{2}{*}{ Compulsory } & Tertiary & 0.899 & 0.981 \\
\hline & & $(0.200)$ & $(0.147)$ \\
\hline \multirow[t]{2}{*}{ Post-compulsory } & Compulsory & 1.054 & 0.412 \\
\hline & & $(0.485)$ & $(0.290)$ \\
\hline \multirow[t]{2}{*}{ Post-compulsory } & Upper secondary & 0.768 & $0.546^{\star}$ \\
\hline & & $(0.231)$ & $(0.172)$ \\
\hline \multirow[t]{2}{*}{ Post-compulsory } & Tertiary & 0.867 & 1.027 \\
\hline & & $(0.251)$ & $(0.242)$ \\
\hline AIC & & 1,775 & 3,789 \\
\hline $\mathrm{BIC}$ & & 1,849 & 3,871 \\
\hline Log-likelihood & & -871 & $-1,879$ \\
\hline
\end{tabular}

Notes: Analytical sub-samples: fathers who reported 'good' or 'very good' health $(\mathrm{N}=4,231)$ and fathers who reported 'very bad', 'bad' or 'fair' health $(\mathrm{N}=2,389)$ at baseline; mothers who reported 'good' or 'very good' health $(\mathrm{N}=4,757)$ and mothers who reported 'very bad', 'bad' or 'fair' health $(\mathrm{N}=3,638)$ at baseline. Reference group is compulsory education for both parents and adult children. All models stratified by country of residence. SE: standard error. AIC: Akaike information criterion. BIC: Bayesian information criterion.

Significance levels: ${ }^{\star} p<0.1,{ }^{\star \star} p<0.05,{ }^{\star \star \star} p<0.01$.

education is clearly associated with parents' survival when fathers and mothers reported from 'very bad' to 'fair' overall health. In particular, having adult children with at least upper secondary education is associated with lower mortality risks for parents with compulsory (and post-compulsory) education who reported poor health at baseline both in early and later older age, compared to the reference group. The latter constitutes evidence that having highly educated adult children may be particularly helpful in mitigating parents' health deterioration after the onset of illness.

Finally, we conducted supplementary analyses to test the robustness of our results by taking into account potential regional differences (Northern, Central 
and Southern Europe), but in this case without distinguishing parents by gender. Although the grouping of parents and countries into three broad regions is a pragmatic response to sample sizes, it nevertheless captures essential differences in family systems and welfare provision. Comparing the results of Table 6, we see first and foremost that the beneficial effect of having highly educated adult children for parents in early older age with only compulsory education is similar in all regional contexts. Having adult children with upper secondary or tertiary education in Northern and Central Europe - but not in Southern Europe - is also associated with lower mortality risks among parents with post-compulsory education in early and later older age, compared to their counterparts with only compulsory education and low-educated adult children.

\section{Discussion}

Our findings largely concur with those from the few previous studies that have identified adult children's education as an important predictor of parents' mortality in middle- and high-income contexts (Zimmer et al., 2002, 2007, 2016; Torssander, 2013, 2014; Friedman and Mare, 2014; Yahirun et al., 2016, 2017; Yang et al., 2016; Elo et al., 2018). Importantly, our study contributes to the growing body of literature on upward health transfers in three ways.

First, it offers new insights into the relationships between children's education and parents' longevity by considering the relative educational attainment of parents and their adult children, and provides sound empirical evidence that, in the European context, ageing adults with low levels of educational attainment who have more highly educated children experience higher survival compared to their counterparts with low-educated children. In other words, while all parents with low educational attainment have a higher mortality risk than more highly educated parents, those with highly educated children have a lower mortality risk than their peers whose children have similar low educational attainment to themselves. Thus, having highly educated children confers a particular mortality advantage on less well-educated fathers and mothers in early older age. This accords with our initial expectations and suggests that having highly educated children could mitigate the independent effect of parental socio-economic disadvantage. It is also consistent with a causal pathway that links the (greater) health knowledge of adult children with the provision of health advice to their parents.

Second, our study indicates that parental age affects the strength and, to a certain extent, the pattern of the association. The benefit of having a highly educated adult child is clearer in early older age than in later older age and is stronger when parents have lower educational attainment than their children, implying that the less there is of one resource (parents' education), the more important another will be (adult children's education) at some ages. So far, only a few studies have provided evidence of differential effects by parental age. Prior work on the USA by Zimmer et al. (2016), for example, has indicated that the effects of adult children's education are attenuated by parental age, arguing that mortality selection and greater homogeneity among individuals surviving at older ages limits opportunities for upward health transfers, which could explain the weaker association for fathers and mothers in later older age found in the current study. In a similar vein, Elo et al. recently 
Table 6. Relative education of parents and adult children predicting parental mortality risks (fathers and mothers combined) for early older age (ages 50 to 74) and later older age (ages 75 and over) by European region (Northern, Central and Southern Europe)

\begin{tabular}{|c|c|c|c|c|}
\hline Parents' education & $\begin{array}{l}\text { Children's } \\
\text { education }\end{array}$ & $\begin{array}{l}\text { Northern } \\
\text { Europe }\end{array}$ & $\begin{array}{l}\text { Central } \\
\text { Europe }\end{array}$ & $\begin{array}{l}\text { Southern } \\
\text { Europe }\end{array}$ \\
\hline & & \multicolumn{3}{|c|}{ Hazard ratios (SE) } \\
\hline \multicolumn{5}{|l|}{ Aged 50-74: } \\
\hline \multirow[t]{2}{*}{ Compulsory } & Upper secondary & 0.706 & 0.844 & 0.914 \\
\hline & & $(0.155)$ & $(0.184)$ & $(0.140)$ \\
\hline \multirow[t]{2}{*}{ Compulsory } & Tertiary & $0.632^{\star}$ & $0.443^{\star \star \star}$ & $0.613^{\star *}$ \\
\hline & & $(0.170)$ & $(0.130)$ & $(0.139)$ \\
\hline \multirow[t]{2}{*}{ Post-compulsory } & Compulsory & 0.757 & 0.519 & 1.192 \\
\hline & & $(0.255)$ & $(0.217)$ & $(0.564)$ \\
\hline \multirow[t]{2}{*}{ Post-compulsory } & Upper secondary & $0.575^{\star \star}$ & $0.652^{\star}$ & 1.056 \\
\hline & & $(0.134)$ & $(0.153)$ & $(0.277)$ \\
\hline \multirow[t]{2}{*}{ Post-compulsory } & Tertiary & $0.649^{\star}$ & $0.459^{\star \star \star}$ & 0.935 \\
\hline & & $(0.152)$ & $(0.111)$ & $(0.240)$ \\
\hline AIC & & 3,232 & 3,310 & 3,450 \\
\hline $\mathrm{BIC}$ & & 3,329 & 3,414 & 3,548 \\
\hline Log-likelihood & & $-1,600$ & $-1,639$ & $-1,709$ \\
\hline Number of subjects & & 3,265 & 5,083 & 3,257 \\
\hline Number of failures & & 244 & 242 & 260 \\
\hline \multicolumn{5}{|l|}{ Aged 75+: } \\
\hline \multirow[t]{2}{*}{ Compulsory } & Upper secondary & 0.773 & 0.843 & 1.234 \\
\hline & & $(0.126)$ & $(0.134)$ & $(0.147)$ \\
\hline \multirow[t]{2}{*}{ Compulsory } & Tertiary & 0.887 & 0.849 & 0.897 \\
\hline & & $(0.167)$ & $(0.149)$ & $(0.133)$ \\
\hline \multirow[t]{2}{*}{ Post-compulsory } & Compulsory & 0.730 & 0.583 & 1.829 \\
\hline & & $(0.259)$ & $(0.241)$ & $(1.439)$ \\
\hline \multirow[t]{2}{*}{ Post-compulsory } & Upper secondary & $0.634^{\star \star}$ & $0.666^{\star}$ & 0.727 \\
\hline & & $(0.142)$ & $(0.139)$ & $(0.283)$ \\
\hline \multirow[t]{2}{*}{ Post-compulsory } & Tertiary & 1.053 & 0.826 & 0.540 \\
\hline & & $(0.199)$ & $(0.163)$ & $(0.195)$ \\
\hline $\mathrm{AIC}$ & & 3,386 & 3,951 & 4,753 \\
\hline $\mathrm{BIC}$ & & 3,463 & 4,036 & 4,831 \\
\hline Log-likelihood & & $-1,677$ & $-1,959$ & $-2,360$ \\
\hline Number of subjects & & 901 & 1,544 & 965 \\
\hline Number of failures & & 312 & 354 & 435 \\
\hline
\end{tabular}

Notes: All models stratified by country of residence within each region: Northern Europe (Denmark, the Netherlands and Sweden); Central Europe (Austria, Belgium, France, Germany and Switzerland); Southern Europe (Greece, Italy and Spain). Reference group is compulsory education for both parents and adult children. All models stratified by country of residence. SE: standard error. AIC: Akaike information criterion. BIC: Bayesian information criterion.

Significance levels: ${ }^{\star} p<0.1,{ }^{\star \star} p<0.05,{ }^{\star \star *} p<0.01$. 
noted for Finland that 'opportunities for children to influence the health of their parents at the oldest ages may be more limited' (2018: 54). These previous findings are supported by our study and are closely aligned to the idea that having highly educated children is most likely to influence parents' longevity when health inequalities among parents reach their peak in the early part of old age when material, behavioural and psycho-social factors, rather than age itself, have a greater impact on health (Davey Smith et al., 1994; Ploubidis et al., 2011). Nonetheless, educational attainment may, of course, be acting as a marker for other resources that adult children with upper secondary or tertiary education bring to their family during their parents' older age. For instance, as noted by Friedman and Mare (2014), better-educated ageing parents may have a greater incentive to adopt new healthy practices suggested by, or observed among, their adult children. Such a possibility already has support in the Taiwanese setting (Zimmer et al., 2007).

The fourth contribution of our study is that the findings provide new evidence on the mechanisms that might link parental longevity and the educational attainment of adult children. It appears that certain health behaviours, as well as health status, underlie the beneficial effects of having highly educated adult children in Europe, particularly for fathers in early older age and for mothers in both early and later older ages. The fact that the associations between relative education and parental mortality risks are somewhat attenuated in our adjusted models when measures of health behaviour (physical (in)activity) and health status (self-reported health) are included implies that adult children's education may play a role in both the prevention and progression of health problems and thus influence parents' survival. Our results are consistent with previous research in the US context (Friedman and Mare, 2014) indicating that physical (in)activity explains part of the association between adult children's education and parents' longevity. Moreover, this supports the contention that influencing parental physical activity habits is part of how adult children's education is translated into survival gains for both fathers and mothers, and corresponds with the 'social influence' pathway identified by Torssander (2013). However, our results also suggest that the influence of adult children's education on parents' longevity operates through a range of aspects related to overall health in both early and later older age. This is not surprising considering that adult children not only provide care to their parents but are also crucial for parents' physical, cognitive and psychological wellbeing at older ages (Seeman, 2000; Marmot et al., 2003). Thus, if well-educated adult children influence their parents' health behaviours, this may not be the only mechanism through which parents derive a health benefit (Yang et al., 2016). Stratification of the full sample into respondents with good and poor health at baseline further revealed that the association between relative education and parents' longevity is significant mainly among parents who already reported poor health both in early and later older age. Our findings thus support previous research by Zimmer et al. (2007: 302) using Taiwanese data, which indicates that adult children's education 'may be important in influencing the course and treatment of disease, determining the progression to recovery or decline and mitigating the effect of disease on mortality'. Although our data only allow speculation about the mechanisms through which having upper secondary/tertiary-educated adult children influence parents' longevity among those who have a health condition, there are several possibilities 
associated with, for example, having greater economic resources, greater health knowledge, the ability to navigate health-care systems, and the ability to understand instructions from doctors or health-care providers in general (Zimmer et al., 2007; Friedman and Mare, 2014).

The 11-year follow-up provided by a well-established survey is a particular strength as it allowed us to investigate the longer-term associations between the relative educational attainment of parents and their adult children and parents' allcause mortality risks, but the SHARE data also impose certain limitations on the analyses. We cannot interpret the associations found as causal as they may be linked to unobserved characteristics, not measured in the data-set, that determine both adult children's education and parents' health. We cannot, for example, exclude the possibility that parents who create the environment for their children to succeed in education are also self-motivated to maintain a healthy lifestyle. Nevertheless, the consistency of our main findings with prior studies that point to the important role that adult children's education can play in influencing parents' health suggests that focusing on the relative educational attainment of parents and their adult children in the analyses enables a more nuanced understanding of the health gradient observed in later life.

The SHARE data-set includes only parents who survived at least to the age of 50 years and are not institutionalised. This may introduce both survivor and selection biases that are likely to affect the analyses for older participants more than the analyses for younger participants as respondents in later older age constitute a particular sample in terms of survival and inclusion. Older participants in SHARE have a higher probability of non-response (Kneip et al., 2015), which could lead to an underestimation of mortality for the oldest-old (Schulz and Doblhammer, 2010). The percentage $(74.2 \%$ for all participating countries from Waves 1 to 5 ) of end-of-life interviews completed by the partner or close relative of respondents whose death was validated (Bergmann et al., 2017) suggests that caution should be exercised when interpreting our findings for those in later older age. Nevertheless, since attrition is generally concentrated among lower socio-economic status individuals (Bergmann et al., 2017) and their mortality risks may thus be underestimated, it is reasonable to expect that our results would be stronger in the absence of attrition. In contrast, attrition should only have a marginal impact on the results for participants in early older age. It is also the case that older parents are less likely than younger parents to have highly educated adult children, given period increases in educational attainment. Thus, the results may reflect both selective and compositional elements of social disadvantage in later life (Batljan and Thorslund, 2009; Hendi, 2015).

The small size of country-specific samples in SHARE precludes single-country analysis and means that our study relies on data pooled from 11 European countries. However, we also performed sensitivity analyses to explore the consistency of our results for three regions (Northern, Central and Southern Europe) reflecting the different European welfare regimes identified by previous theoretical frameworks (Esping-Andersen, 1990; Hank and Jürges, 2010). The results demonstrate that the benefits of having highly educated children are similar in all regional contexts for parents in early older age who have low educational attainment. However, there are also some differences between regions. Notably, while having upper 
secondary- or tertiary-educated adult children among better-educated parents during early older age in Northern and Central Europe is associated with lower mortality compared to the reference group, we do not find a similar association in Southern Europe. Further, while having adult children with upper secondary education in Northern and Central Europe is also associated with lower mortality for parents with post-compulsory education in later older age compared to the reference group, this is not the case for Southern Europe. Although the explanation of this finding warrants further investigation, one possible influence is the presence of larger cohorts of parents with upper secondary/tertiary education in both Northern and Central Europe compared with Southern Europe. Further research is clearly needed as it is possible that the regional patterns we observe may increasingly converge as education levels increase across all European countries (Sanderson and Scherbov, 2016).

\section{Conclusion}

With strong intergenerational relations in Europe (Tomassini et al., 2004), the education of children can have significant and far-reaching effects not only on the broader family unit but also on the societies in which families live. Thus, our findings imply that recent expansions in higher education could reduce the mortality gradient among older generations. The latter might be especially important within the European context where the recent expansion of tertiary education among younger generations has been pronounced. In 2016, 79.6 per cent of people aged 25-54 in the EU-28 (28 member states of the European Union) had at least an upper secondary level of education, compared with 63.7 per cent of those aged 55-74. In the same year, those with tertiary educational attainment constituted 33.4 per cent of those aged 25-54, compared with 20.6 per cent of those aged 55-74 (Eurostat, 2017). While the possibility that further investments in education in one generation may contribute to improved health for those in previous generations is consistent with our findings, one key unanswered question is whether, at the same time, the gap between less well-educated families and the rest will widen. As stated by Zimmer et al. (2016: 1600), if offspring have the means to climb the SES [socio-economic status] hierarchy, they can function to improve the life chances of their low-status parents'. However, if educational expansions mainly exacerbate social competition in education, these can also augment the effects of prior social inequalities (Marginson, 2016).

Our study using SHARE data demonstrates that in Europe having highly educated children confers a particular mortality advantage on less well-educated fathers and mothers. Nonetheless, further investigation is warranted to confirm or refute such effects in other settings. For instance, one may expect that the European context is different from other Western contexts such as the USA where enrolment in higher education tends to be highly socially stratified due to the high costs (especially of college education), with families (not welfare states) bearing much of the financial burden of high tuition fees. While previous research on upward health transfers in the USA and elsewhere has clearly shown the potential importance of children's socio-economic resources for parents' health, a better understanding of the interaction between children's education and their parents' 
longevity increasingly requires an intergenerational approach that is sensitive to their educational differences.

Data. This paper uses data from SHARE Waves 1, 2, 4, 5 and 6 (DOIs: 10.6103/SHARE.w1.600, 10.6103/ SHARE.w2.600, 10.6103/SHARE.w4.600, 10.6103/SHARE.w5.600, 10.6103/SHARE.w6.600), see BörschSupan et al. (2013) for methodological details. The SHARE data collection has been primarily funded by the European Commission through FP5 (QLK6-CT-2001-00360), FP6 (SHARE-I3: RII-CT2006-062193, COMPARE: CIT5-CT-2005-028857, SHARELIFE: CIT4-CT-2006-028812) and FP7 (SHARE-PREP: No. 211909, SHARE-LEAP: No. 227822, SHARE M4: No. 261982). Additional funding from the German Ministry of Education and Research, the Max Planck Society for the Advancement of Science, the US National Institute on Aging (U01_AG09740-13S2, P01_AG005842, P01_AG08291, P30_AG12815, R21_AG025169, Y1-AG-4553-01, IAG_BSR06-11, OGHA_04-064, HHSN271201300071C) and from various national funding sources is gratefully acknowledged (see www.share-project.org).

Acknowledgements. The authors are grateful to the two anonymous reviewers and to the Associate Editor Dr Eric Bonsang for their useful insights and suggestions.

Financial support. This work was supported by the ESRC Centre for Population Change (grant number ES/K007/394/1); and the University of St Andrews.

\section{Note}

1 Full tables with all covariates for fathers and mothers, and all older ages combined and then separately for those in early older age and later older age, are available on request from the corresponding author.

\section{References}

Astone NM, Nathanson CA, Schoen R and Kim YJ (1999) Family demography, social theory, and investment in social capital. Population and Development Review 25, 1-31.

Backlund E, Sorlie PD and Johnson NJ (1999) A comparison of the relationships of education and income with mortality: the National Longitudinal Mortality Study. Social Science and Medicine 49, 1373-1384.

Bambra C, Netuveli G and Eikemo TA (2010) Welfare state regime life courses: the development of western European welfare state regimes and age-related patterns of educational inequalities in self-reported health. International Journal of Health Services 40, 399-420.

Batljan I and Thorslund M (2009) The effect of change in educational composition on population ageing. European Journal of Ageing 6, 191-200.

Bengtson VL and Roberts RE (1991) Intergenerational solidarity in aging families: an example of formal theory construction. Journal of Marriage and the Family 53, 856-870.

Bergmann M, Kneip T, De Luca G and Scherpenzeel A (2017) Survey participation in the Survey of Health, Ageing and Retirement in Europe (SHARE), Wave 1-6. Munich Center for the Economics of Aging (MEA), SHARE Working Paper Series 31-2017.

Berkman LF and Glass T (2000) Social integration, social networks, social support, and health. In Berkman LF and Kawachi I (eds), Social Epidemiology. New York, NY: Oxford University Press, pp. 137-173.

Berniell L, De la Mata D and Valdes N (2013) Spillovers of health education at school on parents' physical activity. Health Economics 22, 1004-1020.

Booth FW, Roberts CK and Lave MJ (2012) Lack of exercise is a major cause of chronic diseases. Comprehensive Physiology 2, 1143-1211.

Börsch-Supan A, Brandt M, Hunkler C, Kneip T, Korbmacher J, Malter F, Schaan B, Stuck S and Zuber S (2013) Data resource profile: the Survey of Health, Ageing and Retirement in Europe (SHARE). International Journal of Epidemiology 42, 992-1001.

Breen R (2010) Educational expansion and social mobility in the 20th century. Social Forces 89, 365-388.

Busemeyer MR, Garritzmann JL, Neimanns E and Nezi R (2018) Investing in education in Europe: evidence from a new survey of public opinion. Journal of European Social Policy 28, 34-54. 
Chandola T, Ferrie J, Sacker A and Marmot M (2007) Social inequalities in self-reported health in early old age: follow-up of prospective cohort study. BMJ 334, 990.

Chapman BP, Fiscella K, Kawachi I and Duberstein PR (2009) Personality, socioeconomic status, and all-cause mortality in the United States. American Journal of Epidemiology 171, 83-92.

Christiansen SG (2014) The impact of children's sex composition on parents' mortality. BMC Public Health 14, 989.

Cullati S, Rousseaux E, Gabadinho A, Courvoisier DS and Burton-Jeangros C (2014) Factors of change and cumulative factors in self-rated health trajectories: a systematic review. Advances in Life Course Research 19, 14-27.

Cutler DM and Lleras-Muney A (2010) Understanding differences in health behaviors by education. Journal of Health Economics 29, 1-28.

Davey Smith G, Blane D and Bartley M (1994) Explanations for socio-economic differentials in mortality: evidence from Britain and elsewhere. European Journal of Public Health 4, 131-144.

De Neve JW and Harling G (2017) Offspring schooling associated with increased parental survival in rural KwaZulu-Natal, South Africa. Social Science and Medicine 176, 149-157.

De Neve JW and Kawachi I (2017) Spillovers between siblings and from offspring to parents are understudied: a review and future directions for research. Social Science and Medicine 183, 56-61.

Delaruelle K, Buffel V and Bracke P (2015) Educational expansion and the education gradient in health: a hierarchical age-period-cohort analysis. Social Science and Medicine 145, 79-88.

Elder GH, Johnson MK and Crosnoe R (2003) The emergence and development of life course theory. In Mortimer JT, Shanahan MJ (eds). Handbook of the Life Course. Boston, MA: Springer, pp. 3-19.

Elo IT (2009) Social class differentials in health and mortality: patterns and explanations in comparative perspective. Annual Review of Sociology 35, 553-572.

Elo IT, Martikainen P and Aaltonen M (2018) Children's educational attainment, occupation, and income and their parents' mortality. Population Studies 72, 53-73.

Esping-Andersen G (1990) The Three Worlds of Welfare Capitalism. Oxford: Polity Press.

Eurostat (2017) Educational Attainment Statistics. Available at http://ec.europa.eu/eurostat/statisticsexplained/index.php/Educational_attainment_statistics\#Level_of_educational_attainment_by_age_and_ sex.

Friedman E and Mare R (2014) The schooling of offspring and the survival of parents. Demography 51, 1271-1293.

Goldman D and Smith JP (2011) The increasing value of education to health. Social Science and Medicine 72, 1728-1737.

Hairi FM, Mackenbach JP, Andersen-Ranberg K and Avendano M (2010) Does socio-economic status predict grip strength in older Europeans? Results from the SHARE study in non-institutionalised men and women aged 50+. Journal of Epidemiology and Community Health 64, 829-837.

Hank K and Jürges $\mathbf{H}$ (2010) The last year of life in Europe: regional variations in functional status and sources of support. Ageing \& Society 30, 1041-1054.

Hendi AS (2015) Trends in US life expectancy gradients: the role of changing educational composition. International Journal of Epidemiology 44, 946-955.

Huijts T, Monden CWS and Kraaykamp G (2010) Education, educational heterogamy, and self-assessed health in Europe: a multilevel study of spousal effects in 29 European countries. European Sociological Review 26, 261-276.

Huisman M, Kunst AE, Bopp M, Borgan JK, Borrell C, Costa G, Deboosere P, Gadeyne S, Glickman M Marinacci C, Minder C, Regidor E, Valkonen T, Mackenbach JP (2005) Educational inequalities in cause-specific mortality in middle-aged and older men and women in eight western European populations. Lancet 365, 493-500.

Huisman M, Kunst AE and Mackenbach JP (2003) Socioeconomic inequalities in morbidity among the elderly; a European overview. Social Science and Medicine 57, 861-873.

Kendig H, Dykstra PA, van Gaalen RI and Melkas T (2007) Health of aging parents and childless individuals. Journal of Family Issues 28, 1457-1486.

Kneip T, Malter F and Sand G (2015) Fieldwork monitoring and survey participation in fifth wave of SHARE. In Malter F and Börsch-Supan A (eds), SHARE Wave 5: Innovations \& Methodology. Munich: MEA, Max Planck Institute for Social Law and Social Policy, pp. 102-159. 
Kravdal Ø (2008) A broader perspective on education and mortality: are we influenced by other people's education? Social Science and Medicine 66, 620-636.

Lakka TA, Kauhanen J and Salonen JT (1996) Conditioning leisure time physical activity and cardiorespiratory fitness in sociodemographic groups of middle-aged men in eastern Finland. International Journal of Epidemiology 25, 86-93.

Lima-Costa MF, Cesar CC, Chor D and Proietti FA (2011) Self-rated health compared with objectively measured health status as a tool for mortality risk screening in older adults: 10-year follow-up of the Bambui Cohort Study of Aging. American Journal of Epidemiology 175, 228-235.

Link BG and Phelan J (1995) Social conditions as fundamental causes of disease. Journal of Health and Social Behavior Extra Issue, 80-94.

Lundborg P and Majlesi K (2015) Intergenerational transmission of human capital: is it a one-way street? Journal of Health Economics 57, 206-220.

Lynch JW, Kaplan GA and Salonen JT (1997) Why do poor people behave poorly? Social Science and Medicine 44, 809-819.

Mackenbach JP (2012) The persistence of health inequalities in modern welfare states: the explanation of a paradox. Social Science and Medicine 75, 761-769.

Marginson S (2016) The worldwide trend to high participation in higher education: dynamics of social stratification in inclusive systems. Higher Education 72, 413-434.

Marmot M, Banks J, Blundell R, Lessof C and Nazroo J (eds) (2003) Health, Wealth and Lifestyles of the Older Population in England: The 2002 English Longitudinal Study of Aging. London: Institute for Fiscal Studies.

Marmot MG, Kogevinas M and Elston MA (1987) Social/economic status and disease. Annual Review of Public Health 8, 111-135.

Modig K, Talbäck M, Torssander J and Ahlbom A (2017) Payback time? Influence of having children on mortality in old age. Journal of Epidemiology and Community Health 71, 424-430.

Monden CWS, van Lentheb F, de Graaf ND and Kraaykampa G (2003) Partner's and own education: does who you live with matter for self-assessed health, smoking and excessive alcohol consumption? Social Science and Medicine 57, 1901-1912.

Peralta M, Martins J, Guedes DP, Sarmento H and Marques A (2017) Socio-demographic correlates of physical activity among European older people. European Journal of Ageing 15, 5-13.

Ploubidis G, de Stavola B and Grundy E (2011) Health differentials in the older population of England: an empirical comparison of the materialist, lifestyle and psychosocial hypotheses. BMC Public Health 11, 390 .

Reczek C, Beth Thomeer M, Lodge AC, Umberson D and Underhill M (2014) Diet and exercise in parenthood: a social control perspective. Journal of Marriage and Family 76, 1047-1062.

Ross CE and Mirowsky J (1999) Refining the association between education and health: the effects of quantity, credential, and selectivity. Demography 36, 445-460.

Ross CE, Mirowsky J and Goldsteen K (1990) The impact of the family on health: the decade in review. Journal of Marriage and Family 52, 1059-1078.

Ross CE and Van Willigen M (1997) Education and the subjective quality of life. Journal of Health and Social Behavior 38, 275-297.

Sabater A and Graham E (2016a) The role of children's education for the mental health of aging migrants in Europe. GeroPsych: The Journal of Gerontopsychology and Geriatric Psychiatry 29, 81-92.

Sabater A and Graham E (2016b) Intergenerational exchanges, children's education and parents' longevity in Europe. ESRC Centre for Population Change, Working Paper Series 77.

Sanderson WC and Scherbov S (2016) A new perspective on patterns of aging in Europe by education and gender. Journal of Population Ageing 9, 207-225.

Schrijvers CT, Stronks K, van de Mheen HD and Mackenbach JP (1999) Explaining educational differences in mortality: the role of behavioral and material factors. American Journal of Public Health 89, $535-540$.

Schulz A and Doblhammer G (2010) Validity of the mortality follow-up in SHARE. Paper presented at the European Population Conference, Vienna, September 1-4. Available at http://epc2010.princeton.edu/ papers/100401.

Seeman TE (2000) Health promoting effects of friends and family on health outcomes in older adults. American Journal of Health Promotion 14, 362-370. 
Skalická V and Kunst AE (2008) Effects of spouses' socioeconomic characteristics on mortality among men and women in a Norwegian longitudinal study. Social Science and Medicine 66, 2035-2047.

Smith KR and Zick CD (1994) Linked lives, dependent demise? Survival analysis of husbands and wives. Demography 31, 81-93.

Smith-Greenaway E, Brauner-Otto S and Axinn W (2018) Offspring education and parental mortality: evidence from South Asia. Social Science Research 76, 157-168.

Stringhini S, Sabia S, Shipley M, Brunner E, Nabi H, Kivimaki M and Singh-Manoux A (2010) Association of socioeconomic position with health behaviors and mortality. Journal of the American Medical Association 303, 1159-1166.

Thomas PA, Lodge AC and Reczek C (2019) Do support and strain with adult children affect mothers' and fathers' physical activity? Research on Aging 41, 164-185.

Tomassini C, Kalogirou S, Grundy E, Fokkema T, Martikainen P, Van Groenou MB and Karisto A (2004) Contacts between elderly parents and their children in four European countries: current patterns and future prospects. European Journal of Ageing 1, 54-63.

Torssander J (2013) From child to parent? The significance of children's education for their parents' longevity. Demography 50, 637-659.

Torssander J (2014) Adult children's socioeconomic positions and their parents' mortality: a comparison of education, occupational class, and income. Social Science and Medicine 122, 148-156.

Umberson D and Karas Montez J (2010) Social relationships and health: a flashpoint for health policy. Journal of Health and Social Behavior 51, S54-S66.

Umberson D, Liu H and Reczek C (2008) Stress and health behaviour over the life course. Advances in Life Course Research 13, 19-44.

Von dem Knesebeck O, Verde PE and Dragano N (2006) Education and health in 22 European countries. Social Science and Medicine 63, 1344-1351.

Yahirun JJ, Sheehan CM and Hayward MD (2016) Adult children's education and parents' functional limitations in Mexico. Research on Aging 38, 322-345.

Yahirun JJ, Sheehan CM and Hayward MD (2017) Adult children's education and changes to parents' physical health in Mexico. Social Science and Medicine 181, 93-101.

Yang L, Martikainen P and Silventoinen K (2016) Effects of individual, spousal, and offspring socioeconomic status on mortality among elderly people in China. Journal of Epidemiology 26, 602-609.

Zimmer Z, Hanson HA and Smith KR (2016) Offspring socioeconomic status and parent mortality within a historical population. Demography 53, 1583-1603.

Zimmer Z, Hermalin AI and Lin HS (2002) Whose education counts? The added impact of adult-child education on physical functioning of older Taiwanese. Journals of Gerontology: Psychological Sciences and Social Sciences 57B, S23-S32.

Zimmer Z, Martin LG, Ofstedal MB and Chuang YL (2007) Education of adult children and mortality of their elderly parents in Taiwan. Demography 44, 289-305. 


\section{Appendix}

Table A1. Relative education of parents and adult children predicting parental mortality risks for all ages (aged 50 and over), early older age (ages 50-74) and later older age (ages 75 and over)

\begin{tabular}{|c|c|c|c|c|}
\hline Parents' education & Children's education & Model 1 & Model 2 & Model 3 \\
\hline & & \multicolumn{3}{|c|}{ Hazard ratios (SE) } \\
\hline \multicolumn{5}{|l|}{ Fathers - all ages: } \\
\hline \multirow[t]{2}{*}{ Compulsory } & \multirow[t]{2}{*}{ Compulsory } & $1.575^{\star \star \star}$ & $1.573^{\star \star \star}$ & $1.512^{\star \star \star}$ \\
\hline & & $(0.192)$ & $(0.191)$ & $(0.186)$ \\
\hline \multirow[t]{2}{*}{ Compulsory } & \multirow[t]{2}{*}{ Upper secondary } & $1.327^{\star \star}$ & $1.324^{\star \star}$ & $1.291^{\star \star}$ \\
\hline & & $(0.147)$ & $(0.147)$ & $(0.144)$ \\
\hline \multirow[t]{2}{*}{ Compulsory } & \multirow[t]{2}{*}{ Tertiary } & 1.099 & 1.106 & 1.085 \\
\hline & & $(0.145)$ & $(0.146)$ & $(0.144)$ \\
\hline \multirow[t]{2}{*}{ Post-compulsory } & \multirow[t]{2}{*}{ Compulsory } & 1.159 & 1.159 & 1.135 \\
\hline & & $(0.244)$ & $(0.243)$ & $(0.239)$ \\
\hline \multirow[t]{2}{*}{ Post-compulsory } & \multirow[t]{2}{*}{ Upper secondary } & 1.014 & 1.005 & 0.999 \\
\hline & & $(0.120)$ & $(0.119)$ & $(0.118)$ \\
\hline AIC & & 10,383 & 10,384 & 10,384 \\
\hline $\mathrm{BIC}$ & & 10,458 & 10,479 & 10,493 \\
\hline Log-likelihood & & $-5,181$ & $-5,178$ & $-5,176$ \\
\hline \multicolumn{5}{|l|}{ Fathers - aged 50-74: } \\
\hline \multirow[t]{2}{*}{ Compulsory } & \multirow[t]{2}{*}{ Compulsory } & $1.870^{\star \star \star}$ & $1.839^{\star \star \star}$ & $1.728^{\star * \star}$ \\
\hline & & $(0.338)$ & $(0.332)$ & $(0.313)$ \\
\hline \multirow[t]{2}{*}{ Compulsory } & \multirow[t]{2}{*}{ Upper secondary } & $1.350^{\star}$ & $1.355^{\star}$ & $1.312^{*}$ \\
\hline & & $(0.217)$ & $(0.217)$ & $(0.210)$ \\
\hline \multirow[t]{2}{*}{ Compulsory } & \multirow[t]{2}{*}{ Tertiary } & 0.978 & 0.986 & 0.960 \\
\hline & & $(0.209)$ & $(0.210)$ & $(0.206)$ \\
\hline \multirow[t]{2}{*}{ Post-compulsory } & \multirow[t]{2}{*}{ Compulsory } & 1.244 & 1.252 & 1.204 \\
\hline & & $(0.348)$ & $(0.349)$ & $(0.337)$ \\
\hline \multirow[t]{2}{*}{ Post-compulsory } & \multirow[t]{2}{*}{ Upper secondary } & 1.119 & 1.086 & 1.071 \\
\hline & & $(0.175)$ & $(0.170)$ & (0.168) \\
\hline AIC & & 4,927 & 4,923 & 4,917 \\
\hline $\mathrm{BIC}$ & & 4,999 & 5,015 & 5,022 \\
\hline Log-likelihood & & $-2,452$ & $-2,447$ & $-2,443$ \\
\hline \multicolumn{5}{|l|}{ Fathers - aged 75+: } \\
\hline \multirow[t]{2}{*}{ Compulsory } & \multirow[t]{2}{*}{ Compulsory } & $1.313^{*}$ & 1.273 & 1.241 \\
\hline & & $(0.211)$ & $(0.204)$ & $(0.205)$ \\
\hline
\end{tabular}


Table A1. (Continued.)

\begin{tabular}{|c|c|c|c|c|}
\hline Parents' education & Children's education & Model 1 & Model 2 & Model 3 \\
\hline \multirow[t]{2}{*}{ Compulsory } & \multirow[t]{2}{*}{ Upper secondary } & 1.213 & 1.169 & 1.145 \\
\hline & & $(0.187)$ & $(0.181)$ & (0.179) \\
\hline \multirow[t]{2}{*}{ Compulsory } & \multirow[t]{2}{*}{ Tertiary } & 1.040 & 1.025 & 1.000 \\
\hline & & $(0.181)$ & $(0.179)$ & $(0.176)$ \\
\hline \multirow[t]{2}{*}{ Post-compulsory } & \multirow[t]{2}{*}{ Compulsory } & 0.841 & 0.826 & 0.820 \\
\hline & & $(0.279)$ & $(0.276)$ & $(0.275)$ \\
\hline \multirow[t]{2}{*}{ Post-compulsory } & \multirow[t]{2}{*}{ Upper secondary } & 0.857 & 0.849 & 0.846 \\
\hline & & $(0.154)$ & $(0.153)$ & $(0.152)$ \\
\hline AIC & & 4,236 & 4,239 & 4,242 \\
\hline $\mathrm{BIC}$ & & 4,293 & 4,312 & 4,326 \\
\hline Log-likelihood & & $-2,107$ & $-2,106$ & $-2,105$ \\
\hline \multicolumn{5}{|l|}{ Mothers - all ages: } \\
\hline \multirow[t]{2}{*}{ Compulsory } & \multirow[t]{2}{*}{ Compulsory } & $1.284^{*}$ & 1.235 & 1.228 \\
\hline & & $(0.165)$ & $(0.162)$ & $(0.165)$ \\
\hline \multirow[t]{2}{*}{ Compulsory } & \multirow[t]{2}{*}{ Upper secondary } & $1.245^{\star}$ & 1.210 & 1.205 \\
\hline & & $(0.150)$ & $(0.146)$ & $(0.148)$ \\
\hline \multirow[t]{2}{*}{ Compulsory } & \multirow[t]{2}{*}{ Tertiary } & 1.050 & 1.028 & 1.024 \\
\hline & & $(0.141)$ & $(0.139)$ & $(0.139)$ \\
\hline \multirow[t]{2}{*}{ Post-compulsory } & \multirow[t]{2}{*}{ Compulsory } & 0.895 & 0.877 & 0.875 \\
\hline & & $(0.249)$ & $(0.244)$ & $(0.244)$ \\
\hline \multirow[t]{2}{*}{ Post-compulsory } & \multirow[t]{2}{*}{ Upper secondary } & 0.884 & 0.876 & 0.874 \\
\hline & & $(0.137)$ & $(0.135)$ & $(0.135)$ \\
\hline AIC & & 11,561 & 11,553 & 11,557 \\
\hline $\mathrm{BIC}$ & & 11,639 & 11,652 & 11,670 \\
\hline Log-likelihood & & $-5,770$ & $-5,763$ & $-5,762$ \\
\hline \multicolumn{5}{|c|}{ Mothers - aged 50-74: } \\
\hline \multirow[t]{2}{*}{ Compulsory } & \multirow[t]{2}{*}{ Compulsory } & $1.586^{\star *}$ & $1.584^{\star *}$ & $1.471^{*}$ \\
\hline & & $(0.319)$ & $(0.321)$ & $(0.310)$ \\
\hline \multirow[t]{2}{*}{ Compulsory } & \multirow[t]{2}{*}{ Upper secondary } & $1.396^{\star}$ & $1.409^{\star}$ & 1.354 \\
\hline & & $(0.257)$ & $(0.257)$ & $(0.253)$ \\
\hline \multirow[t]{2}{*}{ Compulsory } & \multirow[t]{2}{*}{ Tertiary } & 0.929 & 0.938 & 0.909 \\
\hline & & $(0.213)$ & $(0.214)$ & $(0.209)$ \\
\hline \multirow[t]{2}{*}{ Post-compulsory } & \multirow[t]{2}{*}{ Compulsory } & 1.195 & 1.141 & 1.100 \\
\hline & & $(0.465)$ & $(0.447)$ & $(0.432)$ \\
\hline Post-compulsory & Upper secondary & 1.163 & 1.144 & 1.115 \\
\hline
\end{tabular}


Table A1. (Continued.)

\begin{tabular}{|c|c|c|c|c|}
\hline Parents' education & Children's education & Model 1 & Model 2 & Model 3 \\
\hline & & $(0.235)$ & $(0.231)$ & $(0.227)$ \\
\hline AIC & & 4,008 & 4,007 & 4,006 \\
\hline $\mathrm{BIC}$ & & 4,083 & 4,101 & 4,114 \\
\hline Log-likelihood & & $-1,993$ & $-1,989$ & $-1,987$ \\
\hline \multicolumn{5}{|l|}{ Mothers - aged 75+: } \\
\hline \multirow[t]{2}{*}{ Compulsory } & Compulsory & 1.122 & 1.043 & 1.062 \\
\hline & & $(0.193)$ & $(0.186)$ & $(0.191)$ \\
\hline \multirow[t]{2}{*}{ Compulsory } & Upper secondary & 1.162 & 1.089 & 1.101 \\
\hline & & $(0.193)$ & $(0.183)$ & $(0.186)$ \\
\hline \multirow[t]{2}{*}{ Compulsory } & Tertiary & 1.059 & 0.998 & 1.006 \\
\hline & & $(0.189)$ & $(0.181)$ & $(0.182)$ \\
\hline \multirow[t]{2}{*}{ Post-compulsory } & Compulsory & 0.732 & 0.711 & 0.706 \\
\hline & & $(0.288)$ & $(0.280)$ & $(0.277)$ \\
\hline \multirow[t]{2}{*}{ Post-compulsory } & Upper secondary & $0.676^{\star}$ & $0.671^{\star}$ & $0.676^{\star}$ \\
\hline & & $(0.159)$ & $(0.158)$ & $(0.159)$ \\
\hline AIC & & 6,335 & 6,331 & 6,334 \\
\hline $\mathrm{BIC}$ & & 6,397 & 6,410 & 6,424 \\
\hline Log-likelihood & & $-3,156$ & $-3,152$ & $-3,151$ \\
\hline
\end{tabular}

Notes: Reference group is post-compulsory education for parents and tertiary education for adult children. All models stratified by country of residence. Model 1: Adjusted for parents' age, country of birth and number of adult children, as well as age and sex of adult child, and parent-child geographical proximity. Model 2: As Model 1, plus adjustment for marital status and partners' education. Model 3: As Model 2, plus adjustment for household income and household wealth. SE: standard error. AIC: Akaike information criterion. BIC: Bayesian information criterion.

Significance levels: ${ }^{*} p<0.1,{ }^{* *} p<0.05,{ }^{* *} p<0.01$.

Cite this article: Sabater A, Graham E, Marshall A (2020). Does having highly educated adult children reduce mortality risks for parents with low educational attainment in Europe? Ageing \& Society 40, 2635-2670. https://doi.org/10.1017/S0144686X19000795 